\title{
Minimum age of the Neoproterozoic Seven Hundred Acre Island Formation and the tectonic setting of the Islesboro Formation, Islesboro block, Maine
}

\author{
David B. Stewart ${ }^{1}$, Robert D. Tucker ${ }^{2}$, Robert A. Ayuso ${ }^{3}$, and Daniel R. Lux ${ }^{4}$ \\ '926A National Center, U.S. Geological Survey, Reston, VA 20192 \\ ${ }^{2}$ Dept. of Earth and Planetary Sciences, Washington University, St. Louis, MO 63130-4899 \\ ${ }^{3} 954$ National Center, U.S. Geological Survey, Reston, VA 20192 \\ ${ }^{4}$ Dept. of Geological Sciences, University of Maine, Orono, ME 04469
}

Date Received: June 12, 2001

Date Accepted: December 24, 2001

Two platformal stratigraphic sequences occur on Islesboro, Penobscot Bay, Maine. The older Seven Hundred Acre Island Formation is at least $200 \mathrm{~m}$ thick, its base is not exposed, and it makes up fault-bounded blocks of siliceous colourbanded dolomitic marble, muscovite-rich quartzite, coarse-grained splendent muscovite-garnet-staurolite-andalusite schist, and calcareous metapelite, with minor garnet amphibolite and amphibolite. It was initially metamorphosed to lower amphibolite facies and was later retrograded to lower greenschist facies. The lower amphibolite facies metamorphism is Neoproterozoic (670 to $650 \mathrm{Ma}$ ) as inferred from the ${ }^{40} \mathrm{Ar} /{ }^{39} \mathrm{Ar}$ high temperature release spectra of homblende separates. A $\mathrm{U}-\mathrm{Pb}$ zircon age of $646.7 \pm 2.7 \mathrm{Ma}$ obtained for a pegmatite that intruded deformed rocks is taken to be the minimum age of the Formation.

The platformal Islesboro Formation probably unconformably overlies the Seven Hundred Acre Island Formation. It is primarily turbiditic pelite with many beds of quartzite, impure dolomitic marble, some conglomerate, and a few feldsparrich volcaniclastic beds and is thought to be either Neoproterozoic or Cambrian. It was metamorphosed only to lower greenschist facies, possibly in the same event that retrograded the Seven Hundred Acre Island Formation.

Geochemical interpretations of minor and trace element analyses of six amphibolite and four schist samples from the Seven Hundred Acre Island Formation show that the protoliths of the amphibolite samples were intermediate between tholeiitic and within-plate type basaltic flows or dikes that intruded attenuated continental crust, or were eroded from these basalts. Four amphibolite and three schist samples analyzed for $\mathrm{Pb}$ isotopes were found to be enriched in radiogenic $\mathrm{Pb}$. The $\mathrm{Pb}$ isotopic compositions are similar to those in peri-Gondwanan basement rocks from Atlantic Canada.

The peri-Gondwanan Islesboro block was placed against the peri-Gondwanan Middle and Late Cambrian Ellsworth terrane on the east by significant Late Silurian strike-slip faulting. The Late Silurian or Early Devonian Turtle Head dextral strike-slip fault separates the Islesboro block from the peri-Gondwanan St. Croix terrane to the west. The timing and nature of the movements of these faults are given from offsets of the isograds around the zircon-dated Late Silurian Sedgwick Granite $(419.5 \pm 1.4 \mathrm{Ma})$ and South Penobscot Intrusive Suite $(419.2 \pm 2.2 \mathrm{Ma})$. These terranes and others like them in Atlantic Canada make up a composite terrane that is different from the composite Avalonian terranes sensu stricto of southeastern New England and Atlantic Canada. The composite peri-Gondwanan terrane that included the Islesboro block was amalgamated with the margin of ancestral North America in the Silurian.

Deux séquences stratigraphiques en plates-formes sont présentes à Islesboro, dans la baie Penobscot, au Maine. La Formation âgée de Seven Hundred Acre Island a au moins 200 mètres d'épaisseur; sa base n'affleure pas; et elle comporte des blocs limités par des failles de marbre dolomitique siliceux à rubans de couleur, du quartzite riche en muscovite, du schiste à muscovite-grenat-staurolite-andalousite resplendissant à gros grain et des métapélites calcaires, avec une quantité restreinte d'amphibolite et d'amphibolite à grenat. Elle avait initialement subi un métamorphisme jusqu'au faciès amphibolitique inférieur et elle a plus tard régressé à un faciès de schistes verts bas. Le métamorphisme du faciès amphibolitique inférieur est survenu au cours du Protérozoïque supérieur (670 à $650 \mathrm{Ma}$ ) d'après ce qu'on peut déduire des spectres de libération à haute température ${ }^{40} \mathrm{Ar} /{ }^{39} \mathrm{Ar}$ des éléments de la hornblende. L'âge de 646,7 $\pm 2,7 \mathrm{Ma}$ obtenu par datation au U-Pb à partir de zircon dans le cas d'une pegmatite faisant intrusion dans les roches déformées est considéré comme l'âge minimal de la Formation.

La Formation en plate-forme d'Islesboro recouvre probablement de façon discordante la Formation de Seven Hundred Acre Island. Cette formation est principalement constituée de pélite turbiditique comportant de nombreuses strates de quartzite, de marbre dolomitique impur, d'une certaine quantité de conglomérat et de quelques strates volcanoclastiques riches en feldspath. On pense qu'elle remonte au Protérozoïque supérieur ou au Cambrien. Elle s'est seulement métamorphisée jusqu'à un faciès de schistes verts bas, possiblement au cours des mêmes circonstances que celles où a régressé la Formation de Seven Hundred Acre Island.

Une interprétation géochimique des analyses des éléments mineurs et des éléments traces de six amphibolites et de quatre schistes de la Formation de Seven Hundred Acre Island révèle que les protolithes des amphibolites ont constitué des stades intermédiaires entre les écoulements ou les filons intrusifs basaltiques tholéiitiques et intra-plaques ayant fait 
intrusion dans la croûte continentale atténuée, ou qu'ils proviennent de l'érosion de ces basaltes. On a constaté que quatre amphibolites et trois schistes dont on a analysé les isotopes de plomb étaient enrichis en plomb radiogénique. Les compositions isotopiques du plomb sont semblables aux roches du socle périgondwanien des provinces atlantiques.

Le bloc périgondwanien d'Islesboro a été placé contre le terrane périgondwanien du Cambrien moyen et supérieur d'Ellsworth à l'est par la formation de failles décrochantes prononcées au cours du Silurien supérieur. La faille décrochante dextrale du Silurien supérieur ou du Dévonien inférieur de Turtle Head sépare le bloc d'Islesboro du terrane périgondwanien de St. Croix à l'Ouest. Le moment et la nature des mouvements de la formation de ces failles nous sont fournis par les décalages des isogrades obtenus à proximité du granite du Silurien supérieur (situé par dotation à partir de zircon à $419,5 \pm$ 1,4 Ma) ainsi que la suite Penobscot intrusif du Sud (419,2 $\pm 2,2 \mathrm{Ma})$. Ces terranes et d'autres comme eux dans les provinces de l'Atlantique constituent un terrane composite différent des terranes composites avaloniens, au sens strict, présents dans le sud-est de la Nouvelle-Angleterre et dans les provinces de l'Atlantique. Le terrane composite périgondwanien qui comprend le bloc d'Islesboro a été fusionné à la marge de l'Amérique du Nord ancestrale au cours du Silurien.

Traduit par la rédaction

\section{INTRODUCTION}

The Islesboro block, not called a terrane because of its small size, is mostly located in the town of Islesboro, a $25 \mathrm{~km}$ long and $3 \mathrm{~km}$ wide group of islands in Penobscot Bay, midcoastal Maine (Fig. 1). The block extends northeastward under the bay to form an elongate block about $7 \mathrm{~km}$ long and $3 \mathrm{~km}$ wide on the mainland in the town of Castine. This faultbounded block and its regional setting between the Ellsworth terrane on the east and the St. Croix terrane on the west is shown on Fig. 1, and its bedrock geology and the localities for the analyzed samples are shown on Fig. 2. Reports on various aspects of the geology and geophysics of the block were given by Stewart (1974), Stewart and Lux (1988), Stewart et al. (1993, 1995a, 1995b, 1998). Seismic reflection data (Stewart 1998, Fig. 4A) indicate that the Islesboro block and the adjacent terranes are themselves all allochthonous above the east-dipping west-directed Sennebec Pond thrust fault, which beneath Islesboro lies at depths of 7 to $8 \mathrm{~km}$.

The purpose of this paper is to provide a description of the lithostratigraphy, metamorphism, geochemistry, and geochronology of rocks that were studied, and use these to interpret the tectonic setting of deposition, geologic history, and regional geological correlations of rocks in the Islesboro block. The geological time scales used are those of Tucker $e t$ al. (1998), Tucker and McKerrow (1995), and Plumb (1991).

\section{ANALYTICAL METHODS}

\section{Petrographic analysis}

Forty-five samples were used for petrographic examination. In addition, minerals in seven samples, including five that were chemically analyzed, were analyzed by Stewart and M.J.K. Flohr in 1985-86 with an SEMQ electron microprobe that was calibrated using analyzed minerals for internal standards. Iron analyzed was calculated as $\mathrm{FeO}$.

\section{Major, minor and trace element analyses}

Ten samples from the Seven Hundred Acre Island Formation, and one from the muscovite pegmatite on Spruce Island that cuts it, were analyzed for major and trace elements.
Major and trace element data were obtained at the analytical laboratories of the U.S. Geological Survey using standard techniques summarized by Baedecker (1987).

\section{Whole-rock $\mathrm{Pb}$ isotopic compositions}

A subset of seven whole-rock samples, three of schist and four of amphibolite, was analyzed for $\mathrm{Pb}$ isotopic compositions. Whole-rock $\mathrm{Pb}$ isotopes were analyzed at the isotope laboratory of the U.S. Geological Survey, Reston, Virginia, using procedures previously outlined by Ayuso et al. (1996).

\section{$\mathrm{U}-\mathrm{Pb}$ isotopic analysis of zircon}

Two- to eight-kilogram samples for isotopic dating were collected from natural exposures. Following pulverization in a jaw-crusher and rotary disc-mill, accessory minerals were extracted using established techniques of Wilfley table concentration and separation by heavy-liquid and magnetic susceptibility techniques. Zircon was selected from the highpurity mineral separates by handpicking with the aid of a binocular microscope. Faceted prismatic zircon or fragments with external faces were selected, air-abraded, and cleaned as is standard treatment for isotope dilution analysis.

Following a brief (10-15 min) wash in warm $2 \mathrm{~N} \mathrm{HNO}_{3}$, a final selection of grains was made in ethanol. The selected grains were cleaned in warm, distilled $4 \mathrm{~N} \mathrm{HNO}_{3}$ and acetone. Zircon fractions and single-crystals were spiked with a mixed ${ }^{205} \mathrm{~Pb}^{235} \mathrm{U}$ tracer solution and dissolved in distilled $48 \% \mathrm{HF}$ and concentrated $\mathrm{HNO}_{3}$ in sealed TFE Teflon digestion vessels at $210^{\circ} \mathrm{C}$ for 72 hours. Isolation and purification of $\mathrm{Pb}$ and $U$ followed the procedures described in Krogh (1973). Total procedure blanks during the course of these analyses were $1-3 \mathrm{pg}$ for $\mathrm{Pb}$ and less than one $\mathrm{pg}$ for $\mathrm{U}$.

$\mathrm{Pb}$ and $\mathrm{U}$ were loaded on single rhenium filaments with silica gel and phosphoric acid in a clean-air environment; isotopic measurements were made with a Fissons Sector-54 thermal ionization mass spectrometer equipped with eight Faraday detectors and an ion-counting Daly detector. Because of the small amount of $\mathrm{Pb}$ loaded for analysis (in some cases less than $100 \mathrm{pg}$ ), most analyses were performed using peak jumping on the Daly detector. Daly mass bias was periodically 


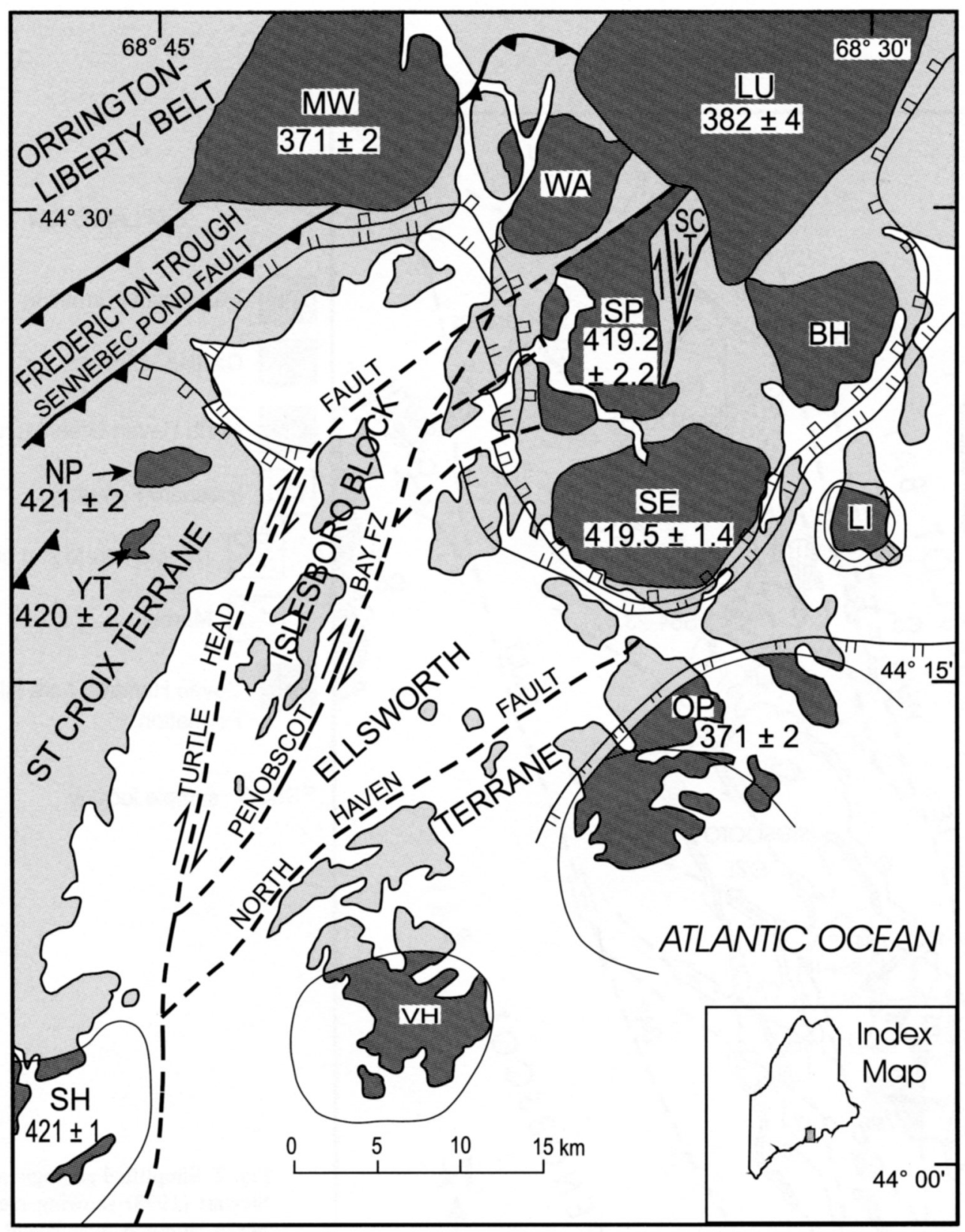

Fig. 1. Simplified geologic map of northern Penobscot Bay, Maine, showing the location of the Islesboro block and adjacent Ellsworth and St. Croix peri-Gondwanan terranes, the principal faults, metamorphic isograds, and plutons after Stewart (1998). The ages of the plutons are from Stewart (1998) and Tucker et al. (2001). Isograds: double barbed decoration = biotite, block decoration = andalusite. Abbreviations for plutons: BH, Blue Hill; LI, Long Island; LU, Luceme; MW, Mount Waldo; NP, Northport; OP, Oak Point; SE, Sedgwick; SH, Spruce Head; SP, South Penobscot; VH, Vinalhaven; WA, Wallamatogus Mountain; YT, Youngtown. SCT = fault block of St. Croix terrane. More details of the Islesboro block are shown in Fig. 2.

monitored with National Institute of Standards and Technology and Central Bureau for Nuclear Measurements isotopic reference materials, and correction factors (and uncertainties) for Daly gain were used in data reduction. Mass-dependent fractionation corrections for $\mathrm{Pb}(0.094 \pm$ $0.025 \% \mathrm{amu}^{-1}$ at $\left.1 \sigma\right)$ and for $U\left(0.111 \pm 0.02 \% \mathrm{amu}^{-1}\right.$ at $\left.1 \sigma\right)$ were applied. For samples with total radiogenic $\mathrm{Pb}$ in excess of $1 \mathrm{ng}$, simultaneous measurements of ${ }^{206} \mathrm{~Pb},{ }^{207} \mathrm{~Pb},{ }^{208} \mathrm{~Pb}$, and ${ }^{205} \mathrm{~Pb}$ were made in Faraday detectors, and ${ }^{204} \mathrm{~Pb}$ and ${ }^{205} \mathrm{~Pb}$ were measured in the Daly detector. In optimum cases an ionbeam between 0.5 and $1.5 \times 10^{-13} \mathrm{~A}$ was maintained for ${ }^{206} \mathrm{~Pb}$ during data acquisition. Uranium was measured as an oxide
$\left(\mathrm{UO}_{2}{ }^{+}\right)$in the Daly detector with an average ${ }^{235} \mathrm{U}$ ion beam intensity of $2.5 \times 10^{-13} \mathrm{~A}$.

Measured ${ }^{206} \mathrm{~Pb} /{ }^{204} \mathrm{~Pb}$ ratios range between 658 and 16,364 , reflecting the low concentration of $\mathrm{Pb}$ in laboratory reagents and materials and the low concentration of common $\mathrm{Pb}$ in zircon. The isotopic composition of the laboratory $\mathrm{Pb}$ is estimated from replicate measurements of reagents and totalprocedure blanks determined since October 1994; values $( \pm 2 \sigma)$ are for the ${ }^{206} \mathrm{~Pb} /{ }^{204} \mathrm{~Pb}=19.4 \pm 2.5 \%,{ }^{207} \mathrm{~Pb} /{ }^{206} \mathrm{~Pb}=$ $0.804 \pm 2.2 \%$, and ${ }^{208} \mathrm{~Pb} /{ }^{206} \mathrm{~Pb}=2.0 \pm 2 \%$. Initial- $\mathrm{Pb}$ compositions are calculated from the $\mathrm{Pb}$-evolution model of Stacey and Kramers (1975) at the estimated age of the rock. 


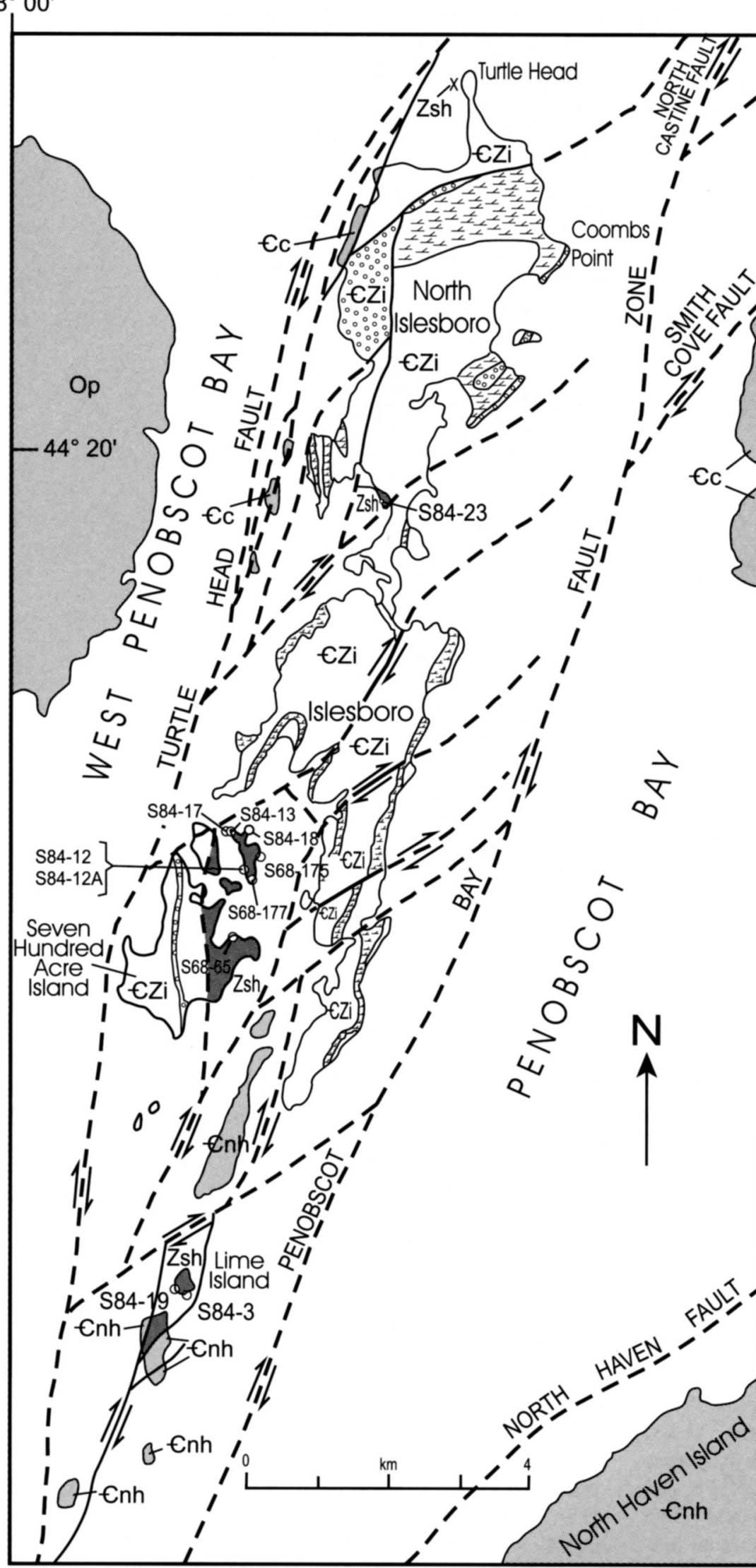

Fig. 2. Simplified geologic map of Islesboro after Stewart (1998) showing mapped fault blocks of Seven Hundred Acre Island Formation, Islesboro Formation, North Haven Greenstone, and Castine Volcanics. Locations are shown for the analyzed samples from the Seven Hundred Acre Island Formation and muscovite granite. Modes of the analyzed samples are given in Appendix A. 
The error of the initial- $\mathrm{Pb}$ compositions is assumed to be $4 \%$ $(2 \sigma)$. In all the cases reported here, even large variations in initial- $\mathrm{Pb}$ compositions result in insignificant changes to the calculated ages. Errors in ${ }^{238} \mathrm{U} /{ }^{206} \mathrm{~Pb},{ }^{235} \mathrm{U} /{ }^{207} \mathrm{~Pb}$, and ${ }^{207} \mathrm{~Pb} /{ }^{206} \mathrm{~Pb}$ were calculated with the algorithm of Ludwig (1980) using a QuickBàsic program written by L. Heaman and D.W. Davis of the Royal Ontario Museum (Toronto).

Because most of the zircon analyses cluster within analytical error of concordia, the cited age is the average of the ${ }^{207} \mathrm{~Pb} /{ }^{206} \mathrm{~Pb}$ ages, weighted according to the inverse variance of the individual ages (Ludwig 1992); the age error is simply the standard error of the average value calculated using the assigned error for each analysis. The reproducibility of the isotopic ages can be evaluated by the mean square of the weighted deviates (MSWD) which is a measure of the observed scatter to that predicted by the assigned errors to each data point. In two of the three samples, the MSWD is much less than one, indicating that the errors assigned to the individual ${ }^{207} \mathrm{~Pb} /{ }^{206} \mathrm{~Pb}$ ages may be somewhat over-estimated. All uncertainties are quoted, and shown in the concordia figures, at the $95 \%$ confidence limit.

\section{${ }^{40} \mathrm{Ar} /{ }^{39} \mathrm{Ar}$ release spectra of hornblende}

The hormblende separates and flux monitors (SGB-7; muscovite, age $240.9 \mathrm{Ma}$ relative to $\mathrm{Mmhb}-1$ ) were wrapped in Sn foil, sealed in silica glass vials and irradiated in the L67 facility of the Ford Nuclear Reactor at the University of Michigan. The irradiation vessel was monitored such that all of the unknowns were within $10 \mathrm{~mm}$ of a flux monitor. Purification of the gases extracted from the flux monitors and unknowns followed standard procedures and the extractionpurification system is on line to the mass spectrometer. The isotopic composition of Ar was measured using a Nuclide 660-SGA 1.25 mass spectrometer at the University of MaineOrono. Data reduction procedures are described in detail by Lux (1986). Ages were calculated using constants recommended by Steiger and Jager (1977). Analytical uncertainties associated with individual steps are at the $2 \sigma$ level. Uncertainties associated with plateau ages are $2 \sigma$ and include a $0.5 \%$ uncertainty in the $\mathrm{J}$-value. The total gas ages represent weighted averages based on the amount of ${ }^{39} \mathrm{Ar}$ in each out-gassed step.

\section{LITHOSTRATIGRAPHY}

\section{Seven Hundred Acre Island Formation}

The Seven Hundred Acre Island Formation was mapped in three fault-bounded blocks, the largest $5 \mathrm{~km}$ by $2 \mathrm{~km}$ and the smallest less than $0.5 \mathrm{~km}$ by $0.5 \mathrm{~km}$, juxtaposed by faults with the Islesboro Formation and Middle Cambrian North Haven Greenstone (Fig. 2). A fourth area about $5 \mathrm{~m}$ by $10 \mathrm{~m}$ was found on the west side of Turtle Head at low tide (Fig. 2). Thin- to thick-bedded, foliated, brown quartzite and muscovitic, sulphidic, and (or) feldspathic quartzite are interbedded with light-grey or buff, siliceous or graphitic, dolomitic marble, coarse-grained, splendent, muscovitegarnet-staurolite-andalusite schist, black hornblende-garnet amphibolite, greenish- or brownish-grey, feldspathic, biotite-, phlogopite-, or idocrase- (pseudomorphs only) gneiss, and some thin, grey to black, graphitic, pelitic beds. Bedding is 1 $\mathrm{cm}$ to $0.5 \mathrm{~m}$ thick and forms aggregate packages of beds that are 2 to $15 \mathrm{~m}$ thick. The formation is at least $200 \mathrm{~m}$ thick but it is complexly folded and faulted so that its true thickness is not known. The base of the formation is not exposed and the basement upon which it was deposited is unknown. The type section is on eastern Seven Hundred Acre Island along the south shore of Cradle Cove and on the south shore of the adjacent Spruce Island in Gilkey Harbour (Stewart 1998). Dark, greenish-black amphibolite occurs throughout the section as dikes and sills of metabasalt, as weakly pillowed flows, or as metamorphosed sediments derived from basalt. Lime Island, in the southern block of exposed Seven Hundred Acre Island Formation, is made up of tightly folded and faulted dolomitic marble with dikes of metabasalt.

The protoliths of the metamorphosed sedimentary rocks of the Seven Hundred Acre Island Formation are interpreted to have been deposited as mature sediments in a platformal sequence. Some protoliths were basalts that were erupted as flows or were intruded as dikes into the Formation or were sediments derived from them.

The age of deposition of the formation is not known; the estimate by Brookins (1976) of this age from a whole-rock $\mathrm{Rb}-\mathrm{Sr}$ isochron age is unreliable. The formation is metamorphosed to lower amphibolite facies and is deformed. The age of post-lower amphibolite facies cooling is estimated to be 670 to $650 \mathrm{Ma}$ based on ${ }^{40} \mathrm{Ar} /{ }^{39} \mathrm{Ar}$ release spectra from hornblende, as described below in the section on geochronology. Muscovite pegmatites intrude the deformed and metamorphosed formation so their age is the same or younger than the age of metamorphism. A muscovite pegmatite on Spruce Island yielded zircon with an age of 647 $\pm 2.7 \mathrm{Ma}$, as described below.

\section{Islesboro Formation}

The sedimentary protoliths of the Islesboro Formation have been metamorphosed to lower greenschist facies. The Islesboro Formation is predominantly light grey to greenishgrey, fine-grained metasiltstone interbedded with quartzite that may be feldspathic or calcareous. Some beds are light purplish-grey. Beds range in thickness from $2 \mathrm{~cm}$ to $20 \mathrm{~cm}$ and have distinct bases and gradational tops. Several stratigraphic successions of quartzite and fine-grained, siliceous, dolomitic marble are shown on Fig. 2 from Stewart (1998). Beds of marble weather rusty brown or dark brown but are light- to medium-grey or bluish grey when freshly broken. Individual beds vary in thickness from $2 \mathrm{~cm}$ to $2 \mathrm{~m}$ and an aggregate package of beds may be up to $6 \mathrm{~m}$ thick. A carbonate unit at Coombs Point was called the Coombs Limestone member by Smith et al. (1907). However, several sequences of sandy and micaceous thinly bedded marble and dolomite occur in the Islesboro Formation (Fig. 2) and cannot all be the same unit, so this member has been abandoned.

Conglomerate sequences up to $20 \mathrm{~m}$ thick are interbedded with quartz-rich metasandstone and metasiltstone in different parts of the overall stratigraphic sequence. Beds of quartzite 
and metaconglomerate with subrounded quartzite or quartz pebbles and cobbles with a sandy matrix typically are 0.5 to 1 $\mathrm{m}$ thick but may be up to $3 \mathrm{~m}$ thick. Some of these beds contain grey chert or red jasper pebbles. Quartz pebble metaconglomerate interbedded with greenish- and purplishgrey metapelite and quartzite forms a band extending from the south to the north across Seven Hundred Acre Island. A $10 \mathrm{~m}$ thick conglomerate sequence overlying dolomitic marble near Coombs Point and Coombs Cove was called Battie Quartzite by Smith et al. (1907), but the Battie member is now known to be part of a quite different lithologic assemblage in the St Croix terrane west of Penobscot Bay (Berry and Osberg 2000).

Some beds rich in plagioclase and chlorite, and containing some lithic clasts possibly originally derived from volcanic wacke, occur on the east side of Turtle Head and in North Islesboro along Main Road. An albitized felsic volcaniclastic bed $2 \mathrm{~m}$ thick occurs in the borrow pit on Kedears Hill, North Islesboro.

The overall thickness of the formation is unknown because of faulting but probably exceeds $700 \mathrm{~m}$. Mafic dikes, as well as a few dacite dikes also metamorphosed to lower greenschist facies, occur locally. Islesboro Island is divided into blocks by right-lateral strike-slip faults that are subparallel to large, regional, strike-slip faults both east and west of the island, as shown by Figs.1 and 2. Most of these blocks are composed of Islesboro Formation except in the southeasternmost part of the town where fault blocks of North Haven Greenstone occur adjacent to both Islesboro and Seven Hundred Acre Island formations. Stratigraphy within the Islesboro Formation can be mapped for kilometres within a fault block, and from one fault block to another (Fig. 2). Folds in the Islesboro Formation have amplitudes and wavelengths of $0.5 \mathrm{~km}$ to at least $2.0 \mathrm{~km}$, and many associated minor folds have axial surfaces with similar northeasterly and northern trends. Detailed studies of the folding and spectacular spaced cleavage developed in graded beds at Turtle Head, Islesboro, were published by Gregg $(1985,1986)$. Folding in the Islesboro Formation is not related to folding in the older Seven Hundred Acre Island Formation.

The Islesboro Formation is a cover sequence of platformal or shallow water slope-rise metasedimentary rocks. Littledeformed beds that are highly variable in thickness probably represent channel fillings. Conglomerate beds composed mostly of quartz pebbles and quartzite cobbles are both normally and reversely graded and were deposited in channels and outwash plains. The Islesboro Formation is interpreted to have been deposited unconformably upon basement of the Seven Hundred Acre Island Formation. However, the unconformity has not been observed, and the Islesboro Formation is separated by faults from basement. These faults are not metamorphic isograds. No evidence of metamorphic minerals or lithic fragments derived from the Seven Hundred Acre Island Formation was found in the metasedimentary rocks in the Islesboro Formation.

\section{Late Silurian granitic plutons}

The timing of movement on the faults that bound the
Islesboro block is constrained by the ages of the Sedgwick Granite and the South Penobscot Intrusive Suite whose contact metamorphic aureoles are cut by these faults. The plutons do not occur in the Islesboro block itself, but lie near its northeastern end in rocks of the Ellsworth terrane (Fig. 1; Stewart 1998). The ages of these plutons have been determined using $\mathrm{U}-\mathrm{Pb}$ on zircons yielding Late Silurian ages, as described in the section on geochronology.

The Sedgwick Granite is a grey, medium- to coarsegrained, equigranular, biotite granite that contains $35 \%$ microcline, $32 \%$ quartz, $28 \%$ oligoclase, $4 \%$ biotite, and trace amounts of zircon, apatite, and titanite. The sample for $\mathrm{U}-\mathrm{Pb}$ dating was collected along route $172,200 \mathrm{~m}$ north of North Sedgwick. Isograds of the contact metamorphic aureole of this pluton are offset by the Penobscot Bay-Smith Cove fault.

The South Penobscot Intrusive Suite is a crudely normally zoned intrusion containing a variety of plutonic rocks that range from massive or layered gabbro to quartz diorite, tonalite, granodiorite, and granite (Stewart et al. 1988). The dated sample (S70-89) is porphyritic Grey Ridge Granite. It is light-grey, coarse-grained, biotite-muscovite granite containing approximately $20 \%$ microcline phenocrysts, and is from the youngest part of the Intrusive Suite (Stewart et al. 1988). The dated sample contains $37 \%$ quartz, $33 \%$ microcline, $26 \%$ oligoclase, $4 \%$ biotite and traces of zircon, apatite, titanite, and muscovite.

\section{METAMORPHISM}

\section{Seven Hundred Acre Island Formation}

The metamorphic mineralogy of the Seven Hundred Acre Island Formation is complex because of the presence of many varieties of metasedimentary rocks and some metabasalt. Rocks with lower amphibolite facies assemblages were faulted and subsequently retrograded to lower greenschist facies. The amount of retrograde metamorphism varies from relatively minor with preserved pseudomorphs of garnet or idocrase, to extensive involving the nearly complete recrystallisation of the lower amphibolite facies assemblage to a lower greenschist assemblage. Rocks retaining the effects of the lower amphibolite facies metamorphism are described first, according to rock type by groups of similar composition or metamorphic assemblage. Effects of the younger lower greenschist facies metamorphism are then described for the same rock types.

\section{Lower amphibolite facies assemblages}

Mapped deformed basaltic dikes and some basaltic flows with relict pillow structures have been metamorphosed to amphibolite. The lower amphibolite facies assemblage is hornblende-plagioclase-titanite-magnetite, but these rocks are most commonly extensively retrograded. Two (S84-12, S8413) of three metabasalts chemically analyzed mostly retain the lower amphibolite assemblage; the third, S84-19, is mostly retrograded to actinolite and chlorite. Hornblende from samples S84-12 and S84-13 (Table 1) has slightly greater amounts of ferrohastingsite than pargasite components 
Table 1. Representative electron microprobe analyses of metamorphic minerals from the Seven Hundred Acre Island Formation

\begin{tabular}{|c|c|c|c|c|c|c|c|c|c|c|c|c|c|c|c|c|c|c|c|c|c|c|c|c|}
\hline Sample \# & $\mathrm{SiO}_{2}$ & $\mathrm{TiO}_{2}$ & $\mathrm{Al}_{2} \mathrm{O}_{3}$ & $\mathrm{FeO}$ & $\mathrm{MnO}$ & $\mathrm{MgO}$ & $\mathrm{CaO}$ & $\mathrm{Na}_{2} \mathrm{O}$ & $\mathrm{K}_{2} \mathrm{O}$ & Total & & & & & & & & & & & & & & \\
\hline \multicolumn{11}{|c|}{$\begin{array}{l}\text { Amphibole an } \\
\text { Hornblende }\end{array}$} & TSi & TAl & $\mathrm{CAl}$ & $\mathrm{CFe}^{3}$ & $\mathrm{CMg}$ & CTi & BMn & $\mathrm{BFe}^{2}$ & $\mathrm{BCa}$ & $\mathrm{BNa}$ & $\mathrm{ANa}$ & $A K$ & $\mathrm{ACa}$ & $\mathrm{Fe \#}$ \\
\hline S84-12 & 41.16 & 0.91 & 13.12 & 19.55 & 0.26 & 8.32 & 11.49 & 1.72 & 0.41 & 98.94 & 6.44 & 1.55 & 0.75 & 2.30 & 1.85 & 0.10 & 0.33 & 0.14 & 1.83 & & 0.50 & 0.09 & 0.01 & 0.57 \\
\hline S84-12A & 42.82 & 0.99 & 14.17 & 19.32 & 0.19 & 7.84 & 11.59 & 1.80 & 0.43 & 99.15 & 6.37 & 1.63 & 0.85 & 2.30 & 1.77 & 0.11 & 0.02 & 0.11 & 1.85 & 0.23 & 0.52 & 0.18 & & 0.58 \\
\hline S84-13 & 45.09 & 1.07 & 9.03 & 18.82 & 0.06 & 10.79 & 11.09 & 2.14 & 1.18 & 99.27 & 6.72 & 1.28 & 0.31 & 2.17 & 2.40 & 0.12 & 0.01 & 0.18 & 1.77 & & 0.62 & 0.23 & & 0.49 \\
\hline \multicolumn{25}{|l|}{ Actinolite } \\
\hline S84-12 & 53.07 & 0.02 & 1.39 & 16.73 & 0.13 & 13.25 & 12.75 & 0.15 & 0.05 & 97.54 & 7.81 & 0.19 & 0.05 & 2.04 & 2.91 & 0.00 & 0.02 & 0.02 & 1.97 & & 0.04 & 0.01 & 0.04 & 0.41 \\
\hline S84-13 & 52.67 & 0.07 & 1.49 & 14.86 & 0.06 & 14.97 & 12.36 & 0.45 & 0.15 & 97.08 & 7.73 & 0.26 & 0.00 & 1.71 & 3.28 & 0.01 & 0.01 & 0.12 & 1.81 & & 0.13 & 0.03 & 0.07 & 0.23 \\
\hline \multicolumn{11}{|c|}{$\begin{array}{l}\text { Mica analyses and structural formulae (based on } 11 \text { oxygen) } \\
\text { Muscovite }\end{array}$} & TSi & TAl & YAl & YMg & YTi & $\mathrm{YFe}^{2}$ & & & & & $\mathrm{ANa}$ & AK & $\mathrm{ACa}$ & $\mathrm{Fe} \#$ \\
\hline S68-65 & 45.44 & 0.03 & 35.88 & 1.69 & n.d. & 0.25 & 0.05 & 0.58 & 9.53 & 93.43 & 3.07 & 0.93 & 1.92 & 0.03 & 0.00 & 0.10 & & & & & 0.08 & 0.82 & 0.01 & 0.79 \\
\hline S68-65 & 45.65 & 0.03 & 35.87 & 1.72 & n.d. & 0.13 & 0.04 & 0.59 & 9.37 & 93.45 & 3.08 & 0.92 & 1.93 & 0.02 & 0.00 & 0.10 & & & & & 0.08 & 0.81 & & 0.88 \\
\hline S68-133 & 47.23 & 0.23 & 33.72 & 1.29 & n.d. & 1.15 & n.d. & 0.50 & 10.08 & 99.20 & 3.17 & 0.83 & 1.83 & 0.12 & 0.01 & 0.07 & & & & & 0.07 & 0.86 & & 0.39 \\
\hline S68-133 & 47.05 & 1.55 & 31.46 & 1.74 & n.d. & 1.53 & 0.01 & 0.31 & 9.92 & 93.55 & 3.19 & 0.81 & 1.70 & 0.15 & 0.08 & 0.10 & & & & & 0.04 & 0.87 & & 0.39 \\
\hline \multicolumn{25}{|l|}{ Phengite } \\
\hline S68-133 & 49.54 & 0.04 & 28.86 & 1.77 & n.d. & 3.84 & 0.05 & 0.18 & 10.02 & 94.30 & 3.32 & 0.68 & 1.60 & 0.38 & 0.00 & 0.10 & & & & & 0.02 & 0.86 & & 0.20 \\
\hline S68-65 & 47.93 & 0.03 & 34.55 & 2.24 & n.d. & 0.12 & 0.02 & 0.62 & 8.78 & 98.80 & 3.19 & 0.81 & 1.90 & 0.01 & 0.00 & 0.12 & & & & & 0.08 & 0.75 & & 0.91 \\
\hline \multicolumn{11}{|c|}{ Chlorite analyses and structural formulae (based on 16 oxygen) } & TSi & TAl & YAl & YMg & YTi & $\mathrm{YFe}^{2}$ & YMn & & & & $\mathrm{ANa}$ & AK & $\mathrm{ACa}$ & Fe\# \\
\hline S84-12 & 25.70 & 0.05 & 20.44 & 30.24 & 0.34 & 12.17 & 0.08 & 0.02 & 0.03 & 89.07 & 5.47 & 2.53 & 2.61 & 3.86 & 0.01 & 5.39 & 0.06 & & & & 0.01 & 0.01 & 0.02 & 0.58 \\
\hline S84-12A & 25.60 & 0.03 & 20.25 & 31.59 & 0.39 & 10.83 & 0.03 & 0.01 & 0.06 & 88.79 & 5.51 & 2.49 & 2.65 & 3.48 & 0.01 & 5.69 & 0.07 & & & & 0.01 & 0.01 & 0.02 & 0.62 \\
\hline S84-13 & 26.72 & 0.02 & 19.36 & 27.26 & 0.08 & 15.73 & 0.05 & 0.06 & 0.06 & 89.32 & 5.58 & 2.42 & 0.34 & 4.90 & 0.00 & 4.76 & 0.01 & & & & 0.03 & 0.02 & 0.01 & 0.49 \\
\hline S68-65 & 26.14 & 0.08 & 22.89 & 33.24 & 0.19 & 6.65 & 0.04 & n.d. & 0.02 & 89.25 & 5.60 & 2.40 & 3.37 & 2.12 & 0.01 & 5.95 & 0.03 & & & & n.d. & 0.01 & 0.01 & 0.74 \\
\hline \multicolumn{11}{|c|}{ Garnet analyses and structural formulae (based on 12 oxygen) } & TSi & TAl & $\mathrm{AAl}$ & $\mathrm{AFe}^{3}$ & ATi & $\mathrm{BMg}$ & BMn & $\mathrm{BFe}^{2}$ & $\mathrm{BCa}$ & Alm & Pyr & Gro & Spe & And \\
\hline S84-12A & 37.59 & 0.07 & 22.20 & 28.10 & 2.66 & 2.49 & 9.47 & 0.01 & n.d. & 102.99 & 2.91 & 0.09 & 1.93 & 0.15 & 0.01 & 0.29 & 0.17 & 1.67 & 0.79 & 57 & 10 & 20 & 6 & 7 \\
\hline S68-65 & 37.89 & 0.07 & 21.99 & 35.96 & 0.68 & 3.06 & 2.83 & 0.01 & n.d. & 102.49 & 2.96 & 0.04 & 2.00 & 0.03 & 0.01 & 0.36 & 0.04 & 2.33 & 0.24 & 78 & 12 & 7 & 2 & 1 \\
\hline \multicolumn{11}{|c|}{ Chloritoid analyses and structural formulae (based on 12 oxygen) } & TSi & TAl & YAl & YMg & YTi & $\mathrm{YFe}^{2}$ & YMn & & & & & & & $\mathrm{Fe} \#$ \\
\hline S68-65 & 24.17 & 0.06 & 40.81 & 26.47 & 0.57 & 1.11 & 0.04 & n.d. & n.d. & 93.27 & 2.00 & 3.00 & 0.98 & 0.14 & 0.00 & 1.83 & 0.04 & & & & & & & 0.93 \\
\hline
\end{tabular}

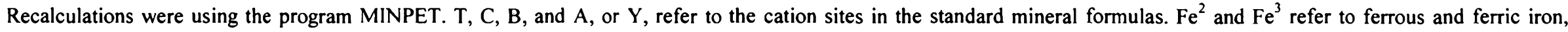
respectively. $\mathrm{Fe} \#=\mathrm{Fe} / \mathrm{Fe}+\mathrm{Mg} ;$ n.d. = not determined. Sample locations are shown on Fig. 2. 
$(\mathrm{Fe} / \mathrm{Fe}+\mathrm{Mg}=0.49$ to 0.57$)$, and has about $1 \% \quad \mathrm{TiO}_{2}$. Plagioclase is present as either relict phenocrysts or interstitial grains, but most of the calcic plagioclase is replaced by zoisite, or as albite plus other greenschist minerals. Quartz content is less than $10 \%$. Titanite and magnetite are common accessory minerals.

Amphibolite and garnet amphibolite derived from sedimentary protoliths are variable in composition. Samples mostly derived from basaltic debris have abundant hornblende and titanite, but also have much quartz and muscovite. Hornblende from sample $\mathrm{S} 84-12 \mathrm{~A}$ has a $\mathrm{Fe} / \mathrm{Fe}+\mathrm{Mg}$ ratio of 0.58 , and contains almost $1 \% \mathrm{TiO}_{2}$, (Table 1). Plagioclase is retrograded to albite. This sample has $10 \%$ garnet crystals up to $6 \mathrm{~mm}$ in size, which are almandine-rich $\left(\mathrm{Alm}_{5 s}\right)$. Trace amounts of apatite and magnetite are also present.

Muscovite - garnet - andalusite - staurolite - biotite plagioclase - quartz splendent schists are important constituents of the Seven Hundred Acre Island Formation. Three of these rocks (S68-65, S68-177, and S84-23) were chemically analyzed (Table 2) and the minerals for two (S6865 , S68-133) were analyzed by electron microprobe. These schists are conspicuous because rounded garnets 2 to $5 \mathrm{~mm}$ across constitute up to $30 \%$ of the rock. Layers of small quartz grains within the garnet might be relicts of beds in the protolith. The garnets are almandine-rich $\left(\mathrm{Alm}_{78} ; \mathrm{S} 68-65\right.$, Table 1). Large muscovite crystals are prominent and are commonly highly sheared so that muscovite is bent. The muscovite has more than $0.85 \mathrm{Al}$ in tetrahedral positions per 11 oxygen and contains about $2 \% \mathrm{FeO}$ and $0.15 \% \mathrm{MgO}$ in solid solution. Andalusite is seldom apparent in hand specimen and staurolite is rare even in thin section. Andalusite is nearly ideal composition but no staurolite was found for analysis in the polished sections.

Siliceous marble contains more than $20 \%$ calcite and a variety of metamorphic minerals including phlogopite, tremolite/actinolite, and graphite. One sample (S84-17) has 2 $\mathrm{cm}$ long square prisms of fine-grained sericite that are interpreted to be pseudomorphs of idocrase. Biotite-rich gneiss with quartz and up to $25 \%$ albitic plagioclase make up some of the metapelitic interbeds within the siliceous marble.

\section{Lower greenschist facies assemblages}

Amphibolite samples vary from rocks containing wellpreserved lower amphibolite facies assemblages to nearly completely retrograded lower greenschist assemblages. In amphibolite samples from lower greenschist assemblages the most common mineral is actinolite with a lower $\mathrm{Fe} / \mathrm{Fe}+\mathrm{Mg}$ ratio than the hornblende it was derived from, low tetrahedral $\mathrm{Al}$, and low alkali content (Table 1). Chlorite is common with a $\mathrm{Fe} / \mathrm{Fe}+\mathrm{Mg}$ ratio nearly the same as in the original hornblende. Titanite is more abundant in retrograde lower greenschist rocks than in lower amphibolite facies rocks. Albite $\left(A n_{<s}\right)$ is common and is associated with retrograde epidote.

Amphibolite inferred to be of meta-sedimentary origin has been strongly retrograded and has gneissic texture. Actinolite has replaced most of the hornblende in many rocks, and it is has a lower $\mathrm{Fe} / \mathrm{Fe}+\mathrm{Mg}$ ratio than the hornblende. Chlorite with approximately equal amounts of ferroan and magnesian components has replaced most of the garnet. Epidote and titanite are abundant, and in some rocks calcite is present is small amounts.

Almost all garnet in the former muscovite-garnetandalusite-staurolite-schist has been retrograded to ferroan chlorite, with $\mathrm{Fe} / \mathrm{Fe}+\mathrm{Mg}=0.72-0.74$ (Table 1). Much of the andalusite and almost all staurolite in these rocks has been retrograded to pleochroic blue-green needles of chloritoid with $\mathrm{Fe} / \mathrm{Fe}+\mathrm{Mg}=0.93$. Some muscovite in fine-grained aggregates with chloritoid is phengitic with low aluminum and higher amounts of $\mathrm{Fe}$ or $\mathrm{Mg}$ in solid solution (Table 1).

Retrograde metamorphic effects in siliceous marble include the formation of sericite pseudomorphs after idocrase (S84-17), chlorite after phlogopite, and the formation of almost pure calcite as the carbonate mineral. Most biotite-rich felsic gneisses are partly to wholly retrograded to chlorite- and albite-rich rocks.

\section{Islesboro Formation}

Regional metamorphism of the Islesboro Formation attained only lower greenschist facies and the mineral assemblages contain abundant quartz, albite, chlorite, muscovite, tremolite in calcite-rich rocks, with minor pyrite and iron oxides, and occasional titanite and tourmaline grains. Chemical equilibration was attained in metamorphism, as no relict calcic plagioclase or biotite was observed in petrographic studies by D.B. Stewart and M.J.K. Flohr (unpublished data). The formation is biotite grade only in the very northeastern most part north of Castine (Fig. 1) where some greenish-brown biotite is present in the contact metamorphic aureole of the South Penobscot Intrusive Suite. The prograde lower greenschist facies metamorphism of the Islesboro Formation is the same grade as that superimposed on the Seven Hundred Acre Island Formation and is presumably of the same age. However, that age has not been determined.

\section{GeOCHEMistry Of THE SEVEn HundRed ACRE ISLAND FORMATION}

\section{Major, minor and trace element analyses}

The major, minor, and trace element compositions of amphibolite, hornblende gneiss, schist, and granite pegmatite are given in Table 2. The abundances of the alkali elements are presumed to be unreliable for classification and for comparison as these rocks all have undergone some degree of alteration. However, the tectonic setting of origin of the protoliths of the amphibolites can be determined on the basis of their $\mathrm{Ti}, \mathrm{Zr}, \mathrm{Nb}$, and $\mathrm{Y}$ contents (Pearce and Norry 1979; Pearce 1996).

Spider diagrams normalized to N-MORB (Pearce 1996) illustrate compositional data for the amphibolite samples from the Seven Hundred Acre Island Formation. Normalized plots for most samples lack spiked spidergrams (Fig. 3a) or pronounced troughs for $\mathrm{Nb}$ and Ta like those typical of calcalkaline rocks (Pearce and Norry 1979; Pearce 1996). Instead, the $\mathrm{Nb}$ and $\mathrm{Ta}$ variations illustrate very small troughs or are 
Table 2. Major and trace element contents and $\mathrm{Pb}$ isotopic compositions of whole rocks from the Seven Hundred Acre Island Formation and pegmatite, southern Maine. See Appendix A for rock names and modes.

\begin{tabular}{|c|c|c|c|c|c|c|c|c|c|c|c|}
\hline Sample & $\begin{array}{l}\text { S84-3 } \\
\text { Amph. }\end{array}$ & $\begin{array}{l}\text { S84-12 } \\
\text { Amph. }\end{array}$ & $\begin{array}{l}\text { S84-12A } \\
\text { Gt. Amph. }\end{array}$ & $\begin{array}{l}\text { S84-13 } \\
\text { Amph. }\end{array}$ & $\begin{array}{c}\text { S84-19 } \\
\text { Amph. Dk. }\end{array}$ & $\begin{array}{l}\text { S68-175 } \\
\text { Hb. Gn. }\end{array}$ & $\begin{array}{l}\text { S68-65 } \\
\text { Sch. }\end{array}$ & $\begin{array}{c}\text { S68-177 } \\
\text { Sch. }\end{array}$ & $\begin{array}{c}\text { S84-23 } \\
\text { Spl. Sch. }\end{array}$ & $\begin{array}{c}\text { S84-17 } \\
\text { Calc. Pel. }\end{array}$ & $\begin{array}{l}\text { S84-18 } \\
\text { Peg. }\end{array}$ \\
\hline \multicolumn{12}{|l|}{ Wt $\%$} \\
\hline $\mathrm{SiO}_{2}$ & 47.70 & 43.70 & 49.20 & 48.30 & 48.30 & 46.50 & 61.40 & 60.60 & 61.50 & 25.50 & 84.30 \\
\hline $\mathrm{Al}_{2} \mathrm{O}_{3}$ & 13.30 & 12.30 & 12.70 & 13.10 & 18.10 & 13.40 & 18.50 & 21.90 & 21.50 & 6.85 & 9.37 \\
\hline $\mathrm{Fe}_{2} \mathrm{O}_{3}{ }^{\mathrm{a}}$ & 15.60 & 19.10 & 17.60 & 15.50 & 10.70 & 12.10 & 10.80 & 6.03 & 1.78 & 2.29 & 0.37 \\
\hline $\mathrm{MgO}$ & 6.70 & 7.78 & 5.59 & 5.87 & 6.06 & 11.80 & 1.54 & 0.51 & 0.88 & 15.30 & 0.31 \\
\hline $\mathrm{CaO}$ & 6.97 & 9.01 & 8.93 & 7.32 & 7.66 & 9.56 & 0.56 & 0.02 & 0.02 & 18.20 & 0.21 \\
\hline $\mathrm{Na}_{2} \mathrm{O}$ & 3.42 & 1.43 & 1.73 & 4.67 & 3.11 & 1.18 & 0.41 & 0.40 & 0.72 & 1.16 & 1.90 \\
\hline $\mathrm{K}_{2} \mathrm{O}$ & 0.90 & 0.34 & 0.36 & 0.68 & 1.63 & 1.63 & 2.57 & 5.77 & 6.27 & 1.71 & 1.92 \\
\hline $\mathrm{TiO}_{2}$ & 2.68 & 3.65 & 2.16 & 2.50 & 1.24 & 0.75 & 0.93 & 0.84 & 0.75 & 1.05 & 0.11 \\
\hline $\mathrm{P}_{2} \mathrm{O}_{5}$ & 0.28 & 0.29 & 0.17 & 0.22 & 0.17 & 0.06 & 0.13 & 0.05 & 0.05 & 0.09 & 0.10 \\
\hline $\mathrm{MnO}$ & 0.17 & 0.28 & 0.24 & 0.02 & 0.12 & 0.18 & 0.10 & 0.02 & 0.02 & 0.04 & $<0.02$ \\
\hline $\mathrm{CO}_{2}$ & - & - & - & - & 0.24 & 0.01 & 0.01 & 0.01 & 0.01 & - & - \\
\hline $\mathrm{S}$ & 0.03 & - & - & - & 0.03 & 0.01 & 0.32 & 0.01 & 0.03 & - & - \\
\hline $\mathrm{Cl}$ & 0.08 & - & - & - & 0.02 & 0.05 & 0.01 & 0.01 & 0.03 & - & - \\
\hline $\mathrm{F}$ & 0.08 & - & - & - & 0.07 & 0.05 & 0.05 & 0.12 & 0.09 & - & - \\
\hline $\mathrm{H}_{2} \mathrm{O}^{+}$ & 2.4 & - & - & - & 3.0 & 2.7 & 3.0 & 5.2 & 5.3 & - & - \\
\hline $\mathrm{H}_{2} \mathrm{O}^{-}$ & 0.63 & - & - & - & 0.60 & 0.44 & 0.70 & 0.44 & 0.56 & - & - \\
\hline $\mathrm{LOI}^{\mathrm{b}}$ & - & 1.99 & 1.75 & 1.48 & - & - & - & - & - & 27.90 & 1.10 \\
\hline Subtotal & $\overline{100.94}$ & - & - & - & $\overline{101.05}$ & $\overline{100.42}$ & $\overline{101.03}$ & $\overline{101.93}$ & $\overline{99.51}$ & & \\
\hline Less $\mathrm{O} \equiv \mathrm{F}$ & 0.07 & - & - & - & 0.05 & 0.04 & 0.19 & 0.06 & 0.06 & & \\
\hline Total & 100.9 & $\overline{99.9}$ & $\overline{100.4}$ & $\overline{99.7}$ & 101.0 & 100.4 & 100.8 & 101.9 & $\overline{99.5}$ & 100.1 & 99.7 \\
\hline \multicolumn{12}{|c|}{ Trace elements, ppm } \\
\hline $\mathrm{Rb}$ & 12 & 6 & $<2$ & 17 & 43 & 77 & 100 & 214 & 232 & 25 & 54 \\
\hline $\mathrm{Sr}$ & 125 & 115 & 187 & 109 & 320 & 99 & 85 & 53 & 48 & 83 & 36 \\
\hline $\mathrm{Ba}$ & 217 & 40 & 53 & 45 & 354 & 333 & 454 & 565 & 738 & 86 & 329 \\
\hline $\mathrm{Pb}$ & 5 & 5 & - & - & 5 & 5 & 5 & 5 & 5 & - & - \\
\hline $\mathrm{La}$ & 11.70 & 15.40 & 10.10 & 24.80 & 12.50 & 5.46 & 38.50 & 31.10 & 29.20 & 4.13 & 5.77 \\
\hline $\mathrm{Ce}$ & 28.10 & 36.30 & 22.90 & 53.05 & 25.40 & 13.00 & 76.10 & 57.80 & 59.00 & 9.10 & 10.60 \\
\hline $\mathrm{Nd}$ & 17.7 & 26.3 & 12.0 & 26.3 & 14.8 & 8.7 & 31.4 & 24.1 & 22.4 & 4.0 & 5.5 \\
\hline $\mathrm{Sm}$ & 5.18 & 7.60 & 4.76 & 6.38 & 3.84 & 2.20 & 6.87 & 4.64 & 4.61 & 1.18 & 1.24 \\
\hline $\mathrm{Eu}$ & 1.72 & 2.40 & 1.48 & 1.95 & 1.21 & 0.75 & 1.31 & 0.96 & 0.91 & 0.29 & 0.34 \\
\hline $\mathrm{Tb}$ & 1.10 & 1.58 & 0.93 & 0.98 & 0.62 & 0.42 & 1.00 & 0.62 & 0.55 & 0.22 & 0.23 \\
\hline $\mathrm{Yb}$ & 3.61 & 6.02 & 3.44 & 3.19 & 2.18 & 1.45 & 3.08 & 3.13 & 2.26 & 0.87 & 0.92 \\
\hline Lu & 0.50 & 0.76 & 0.50 & 0.47 & 0.33 & 0.22 & 0.43 & 0.45 & 0.35 & 0.13 & 0.11 \\
\hline Y & 34 & 57 & 31 & 33 & 2 & 11 & 36 & 32 & 2 & 4 & 11 \\
\hline $\mathrm{Zr}$ & 168 & 133 & 111 & 156 & 95 & 52 & 233 & 118 & 92 & 125 & 30 \\
\hline $\mathrm{Hf}$ & 4.39 & 3.97 & 3.21 & 4.11 & 2.27 & 1.23 & 6.11 & 3.21 & 2.49 & 3.01 & 0.46 \\
\hline $\mathrm{Nb}$ & 23 & 14 & $<10$ & 21 & 18 & $<10$ & 11 & 19 & 14 & 20 & 13 \\
\hline $\mathrm{Ta}$ & 1.72 & 0.84 & 0.65 & 1.43 & 0.94 & 0.44 & 0.90 & 1.09 & 0.94 & 1.22 & 0.29 \\
\hline Th & 1.71 & 1.54 & 1.05 & 1.90 & 1.27 & 0.72 & 11.50 & 12.32 & 2.65 & 4.50 & 1.71 \\
\hline $\mathrm{U}$ & 0.36 & 0.55 & 0.24 & 0.62 & 0.25 & 0.20 & 2.76 & 1.28 & 1.1 & 2.23 & 0.64 \\
\hline Sc & 43.5 & 78.1 & 45.0 & 42.4 & 33.2 & 32.1 & 17.7 & 23.8 & 20.8 & 10.5 & 16.0 \\
\hline $\mathrm{Cr}$ & 132.4 & 44.3 & 47.9 & 29.4 & 100.4 & 963.0 & 124.0 & 136.8 & 109.0 & 67.4 & 9.5 \\
\hline Co & 41.20 & 54.00 & 54.40 & 26.15 & 33.40 & 39.40 & 41.00 & 14.88 & 0.66 & 0.60 & 0.39 \\
\hline $\mathrm{Ni}$ & 68 & 60 & 46 & 43 & 53 & 240 & 100 & 69 & 5 & $<24$ & $<26$ \\
\hline${ }^{206} \mathrm{~Pb} /{ }^{204} \mathrm{~Pb}$ & 20.871 & 21.057 & - & - & 19.718 & 19.021 & 17.955 & 21.083 & 24.223 & $\cdot$ & - \\
\hline${ }^{207} \mathrm{~Pb} /{ }^{204} \mathrm{~Pb}$ & 15.891 & 15.989 & - & - & 15.786 & 15.684 & 15.697 & 15.923 & 16.173 & - & - \\
\hline${ }^{208} \mathrm{~Pb} /{ }^{204} \mathrm{~Pb}$ & 38.663 & 41.316 & - & - & 37.647 & 39.541 & 37.659 & 42.954 & 43.493 & - & - \\
\hline
\end{tabular}

${ }^{\mathrm{a}}$ Total iron as $\mathrm{Fe}_{2} \mathrm{O}_{3},{ }^{b}$ Loss on ignition at $900^{\circ} \mathrm{C}$ 

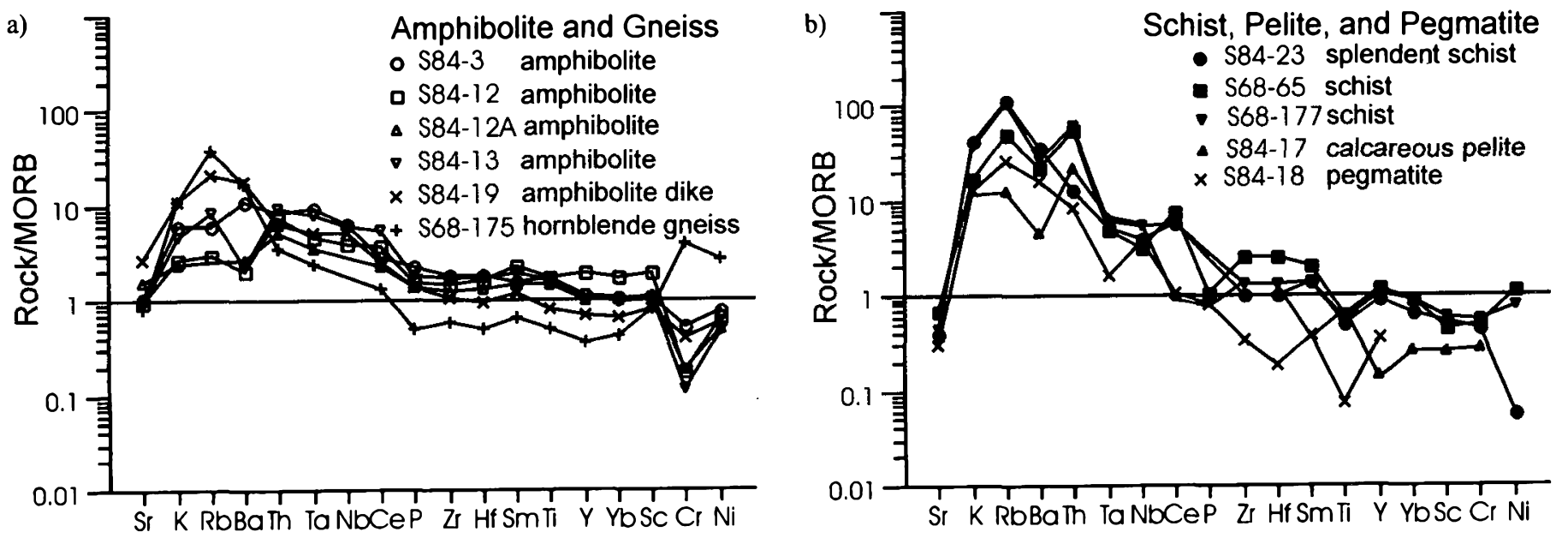

Fig. 3. Spider diagrams of a) amphibolite and hornblende gneiss samples and b) schist, metapelite, and pegmatite samples from the Seven Hundred Acre Island Formation normalized to N-MORB (Pearce 1996).

slightly enriched relative to the abundances of Th and Ce. The amphibolites lack troughs for $\mathrm{Ti}$ and $\mathrm{Sc}$ though they have moderate troughs for $\mathrm{Cr}$, indicating fractionation of $\mathrm{Fe}-\mathrm{Ti}$ oxides.

The normalized diagram for the schist samples (Fig. 3b) shows small troughs at $\mathrm{Ba}, \mathrm{Ta}, \mathrm{Nb}, \mathrm{Sr}$, and $\mathrm{P}$ (and $\mathrm{Ti}$ ?) and a general enrichment for $\mathrm{K}, \mathrm{Rb}$, and $\mathrm{Th}$. The small relative depletions in $\mathrm{Nb}$ and $\mathrm{Ta}$ relative to $\mathrm{Th}$ and $\mathrm{Ce}$ in these samples are compatible with an origin in an orogenic arc (Pearce and Norry 1979; Pearce 1996).

Chondrite-normalized variations for the REE show that the amphibolite samples (Fig. 4a) have flat REE patterns and no evidence for depletion of Eu by plagioclase fractionation or the heavy REE (HREE) by garnet fractionation. In contrast, the schist samples as a group are light REE (LREE) enriched (from about $10 \times$ to about $100 \times$ chondrite) and generally display smooth patterns (Fig. 4b). The HREE patterns are flat and some of the samples have small to moderate negative Eu anomalies.

Although the number of amphibolite samples in the study is limited, immobile trace element abundances (Fig. 3a) and their ratios (Th, Hf, Ta, Yb, etc.) as in Fig. 5 (after Wood

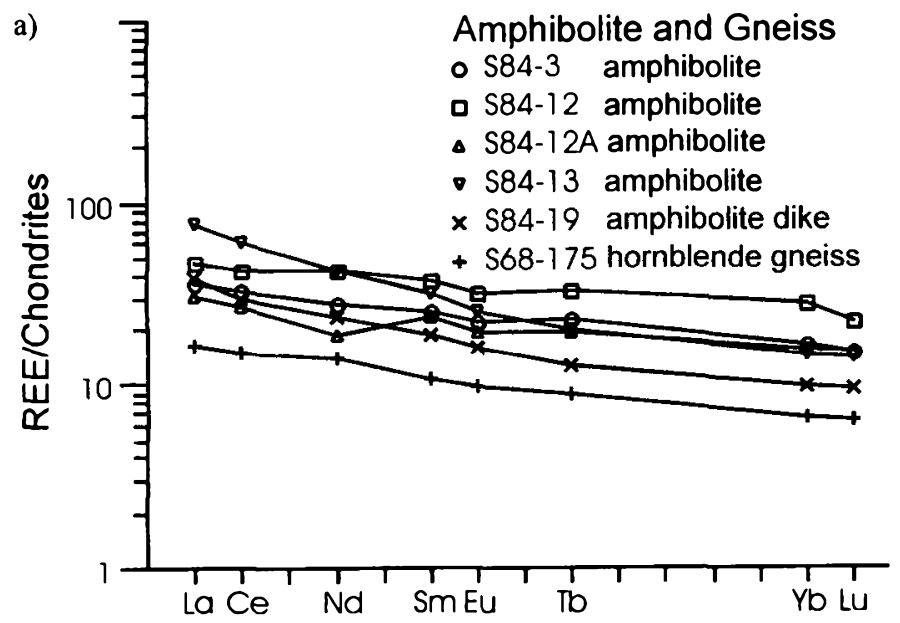

1980) are meaningful even if the rocks have been affected by metamorphic processes. Such trace element features can be used to estimate the original magmatic compositions of the mafic rocks and infer the nature of their sources and tectonic settings.

The schist samples have widely variable compositions and are insufficient in number for detailed geochemical interpretation. Their trace element abundances resemble those of granitic rocks from arc environments (e.g., $\mathrm{Ta}$ and $\mathrm{Yb}$; Pearce et al. 1984).

\section{$\mathrm{Pb}$ isotopes}

$\mathrm{Pb}$ isotopic compositions of whole rocks from the Seven Hundred Acre Island Formation exhibit a wide range in ${ }^{206} \mathrm{~Pb}^{1204} \mathrm{~Pb}$ from about 17.96 to 24.22 , in ${ }^{207} \mathrm{~Pb}^{1204} \mathrm{~Pb}$ from 15.68 to 16.17 , and ${ }^{208} \mathrm{~Pb}^{1204} \mathrm{~Pb}$ from 37.65 to 43.49 (Table 2). Age-corrected compositions (at $647 \mathrm{Ma}$ ) using measured $\mathrm{U}$, $\mathrm{Th}$, and $\mathrm{Pb}$ abundances are shown in Fig. 6. The $\mathrm{Pb}$ isotopic compositions are more radiogenic than the average $\mathrm{Pb}$ crustal evolution curve (Stacey and Kramers 1975) and attest to the contributions of evolved isotopic reservoirs in continental crust.

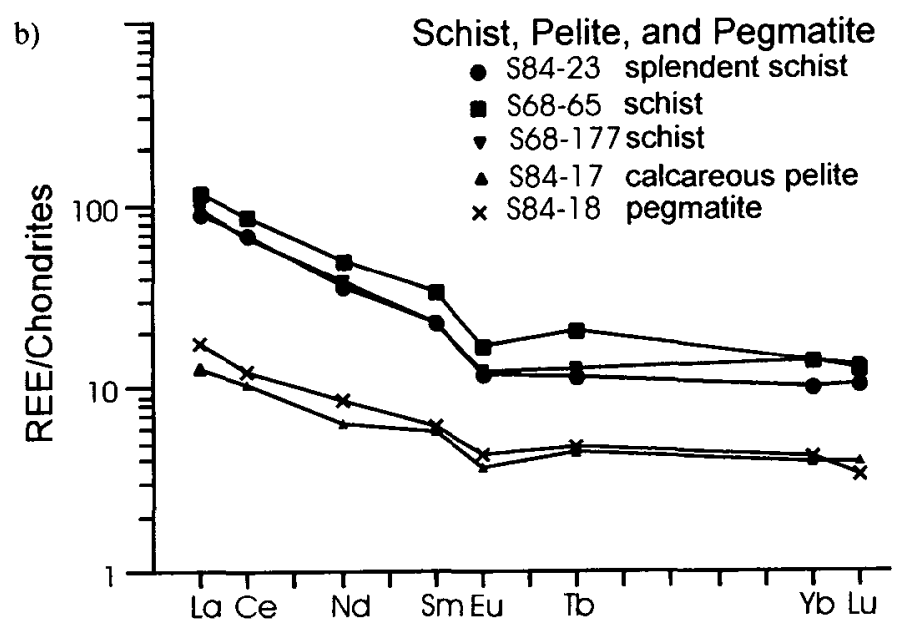

Fig. 4. Chondrite-normalized REE plots for a) amphibolite and hornblende gneiss samples and b) schist and metapelite samples from the Seven Hundred Acre Island Formation and from pegmatite that intruded it. 


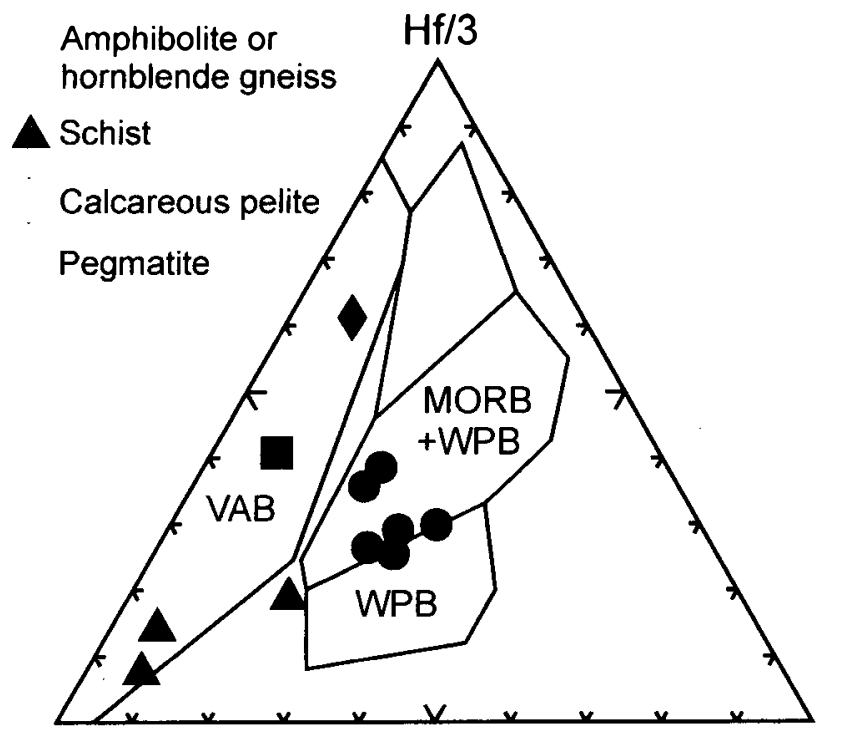

Fig. 5. Th-Hf-Ta diagram showing compositions of rocks from the Seven Hundred Acre Island Formation and from pegmatite that intruded it. The amphibolite samples have tectonomagmatic affinities resembling E-type MORB and within-plate tholeiite sources; they also overlap the field for alkaline within-plate basalts. Labelled fields from Wood (1980) and Pearce (1996): VAB, volcanic arc basalt; MORB, mid-ocean ridge basalt and within plate basalt (E-type MORB, enriched-type of mid-ocean ridge basalt); WPB, within-plate basalt.

Th $\mathrm{Ta}$

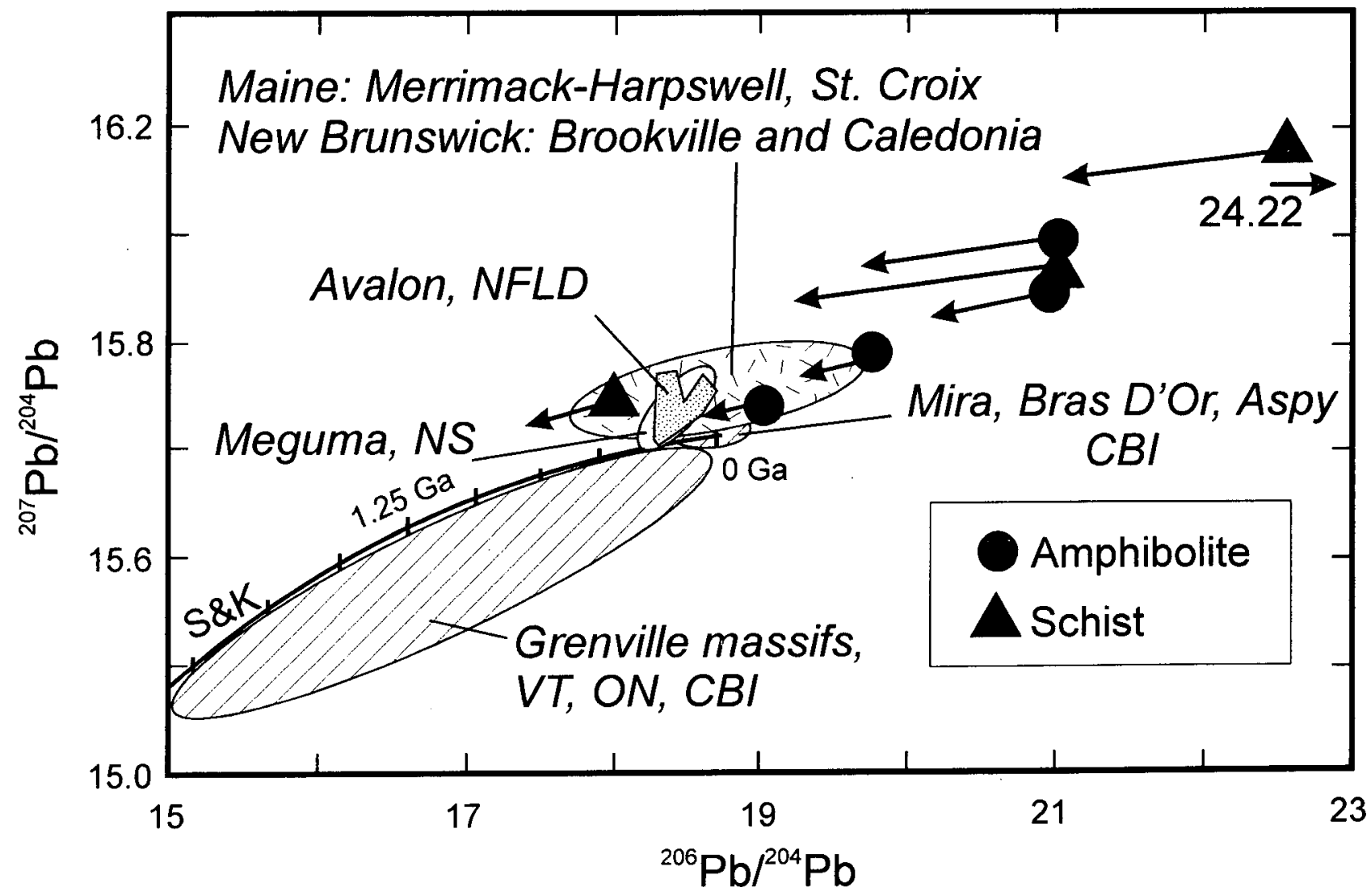

Fig. 6. ${ }^{207} \mathrm{~Pb} /{ }^{204} \mathrm{~Pb}$ vs. ${ }^{206} \mathrm{~Pb} /{ }^{204} \mathrm{~Pb}$ isotopic compositions of rocks from the Seven Hundred Acre Island Formation and comparisons to Grenville massifs and peri-Gondwanan basements from New England and Atlantic Canada. Vectors illustrate the direction and estimated change in $\mathrm{Pb}$ isotopic compositions of the amphibolite and schist from the Seven Hundred Acre Island Formation using measured $\mathrm{U}$, Th, and $\mathrm{Pb}$ contents at 647 Ma. Sources of data: VT, Grenville basement rocks (gneisses and schists) from Vermont (R. Ayuso and N. Ratcliffe, unpublished data for Green Mountains Massif, 1996); ON, Ontario (DeWolf and Mezger 1994); CBI, Blair River complex (gneiss) in Cape Breton Island (Ayuso et al. 1996); peri-Gondwanan basement rocks in New Brunswick (Ayuso and Bevier 1991; Whalen et al. 1996a); granitic plutons and gneisses from the Mira, Aspy, and Bras d'Or blocks in Cape Breton Island (CBI) (Ayuso et al. 1996); peri-Gondwanan gneisses from the Brookville and Caledonia blocks from New Brunswick, the Merrimack-Harpswell and St. Croix blocks from Maine, and Paleozoic granitic rocks from the Northern Appalachians of New England and Atlantic Canada (e.g., Ayuso 1999; Ayuso and Bevier 1991; Ayuso et al. 1996; Ayuso and Arth 1997; Whalen et al. 1994a, b; 1996a, b); Devonian granitic rocks from the Canso area, Meguma block, Nova Scotia (NS) (R. Ayuso and J. Hill, unpublished data, 1994); granitic rocks from the Ackley batholith in the Avalon of Newfoundland (NFLD) (R. Ayuso, D. Kontak and D. Strong, unpublished data, 1994); crustal evolution curve (S\&K, Stacey and Kramers 1975) showing tick marks at 0.25 Ga. 


\section{GEOCHRONOLOGY}

\section{$\mathrm{U}-\mathrm{Pb}$ ages of zircon}

\section{Muscovite pegmatite at Spruce Island}

The muscovite pegmatite cuts dolomitic limestone in metamorphic rocks at lower amphibolite grade at the northeast end of Spruce Island. The pegmatite is weakly cleaved but quite fresh. A whole rock chemical analysis of pegmatite sample S84-18 is given in Table 2 and a modal estimate is given in the appendix. Two zircon fractions for sample RT537HA-5, one of 3 grains and one single grain, were analyzed (Table 3). One is $0.8 \%$ discordant with a ${ }^{207} \mathrm{~Pb} /{ }^{206} \mathrm{~Pb}$ age of $646 \pm 3 \mathrm{Ma}$ and the other is $2.9 \%$ discordant with a ${ }^{207} \mathrm{~Pb} /{ }^{206} \mathrm{~Pb}$ age of $649 \pm 6 \mathrm{Ma}$. Uranium contents approach $2500 \mathrm{ppm}$ so some $\mathrm{Pb}$-loss arising from radiation damage is possible. If discordance arises from time integrated $\mathrm{Pb}-$ loss the ${ }^{207} \mathrm{~Pb} /{ }^{206} \mathrm{~Pb}$ age is the best estimate of the age of pegmatite emplacement. The weighted mean ${ }^{207} \mathrm{~Pb} /{ }^{206} \mathrm{~Pb}$ age of the two analyses is $646.7 \pm 2.7 \mathrm{Ma}$ (Fig. 7a). Estimates of the age of this pegmatite given in Brookins (1976) are incorrect.

\section{Sedgwick Granite}

A sample of granite of the Sedgwick Granite was collected along Route 172, $200 \mathrm{~m}$ north of North Sedgwick. Zircon from this sample, RT-93SP-17, is dominated by a population of clear long-prismatic faceted prisms. Three fractions of long, prismatic grains were analyzed (Table 3 ). All are concordant within error and only moderate age discordance is observed $(0.22-0.37 \%$, Fig. $7 \mathrm{~b})$. Whereas the weighted-average of the ${ }^{206} \mathrm{~Pb} /{ }^{238} \mathrm{U}$ ages is $418.3 \pm 2.0 \mathrm{Ma}$, the weighted-average ${ }^{207} \mathrm{~Pb} /{ }^{206} \mathrm{~Pb}$ age is $419.5 \pm 1.4 \mathrm{Ma}$ (Fig. $7 \mathrm{~b}$ ). The difference between the two can be attributed to less than $0.4 \%$ of $\mathrm{Pb}$-loss, and the ${ }^{207} \mathrm{~Pb} /{ }^{206} \mathrm{~Pb}$ age may therefore be the best estimate of the time of granite emplacement. Using the time-scale of Tucker and McKerrow (1995) a latest Silurian (Ludlow or Pridoli) emplacement age is implied. The weighted average ${ }^{207} \mathrm{~Pb} /{ }^{206} \mathrm{~Pb}$ is well defined $(\mathrm{MSWD}=0.766$ ) indicating that the assigned errors to the individual ${ }^{207} \mathrm{~Pb} /{ }^{206} \mathrm{~Pb}$ ages encompass the true age.

\section{Grey Ridge Granite, South Penobscot Intrusive Suite}

A sample (S70-89) of the Grey Ridge Granite, the youngest phase of the South Penobscot Intrusive Suite, yielded a zircon concentrate that had been previously studied by T.W. Stern (in Stewart et al. 1988, p. 90) to obtain an age of $424.4 \pm$ $6 \mathrm{Ma}$. Two samples of clear and one ample of pale brown flat or long prisms and one sample of pale brown long prisms (Table 3) were selected from this concentrate for further study. The weighted mean ${ }^{207} \mathrm{~Pb} /{ }^{206} \mathrm{~Pb}$ age for these nearly concordant samples is $419.2 \pm 2.2 \mathrm{Ma}$ (Fig. 7c), and this is taken to be the age of the youngest part of the South Penobscot Intrusive Suite.

Table 3. U-Pb isotope dilution analyses.

\begin{tabular}{|c|c|c|c|c|c|c|c|c|c|c|c|}
\hline \multicolumn{3}{|c|}{ Fractions } & \multicolumn{3}{|c|}{ Concentrations } & \multicolumn{5}{|c|}{ Atomic Ratios } & \multirow{2}{*}{$\begin{array}{c}\text { Ages } \\
\frac{{ }^{207} \mathrm{~Pb}}{{ }^{206} \mathrm{~Pb}} \\
(6)\end{array}$} \\
\hline No. & $\begin{array}{c}\text { Properties } \\
\text { (1) }\end{array}$ & $\begin{array}{l}\text { Wt. } \\
\mu \mathrm{g} \\
(2)\end{array}$ & $\begin{array}{c}\mathrm{Pb}^{*} \\
\mathrm{ppm} \\
(2)\end{array}$ & $\begin{array}{c}\text { U } \\
\mathrm{ppm} \\
(2)\end{array}$ & $\begin{array}{l}\mathrm{Pb} \\
\mathrm{pg} \\
(3)\end{array}$ & $\begin{array}{l}\frac{T h}{U} \\
(4)\end{array}$ & $\begin{array}{c}\frac{{ }^{206} \mathrm{~Pb}}{{ }^{204} \mathrm{~Pb}} \\
(5)\end{array}$ & $\begin{array}{c}\frac{{ }^{207} \mathrm{~Pb}}{{ }^{206} \mathrm{~Pb}} \\
(6)\end{array}$ & $\begin{array}{c}\frac{{ }^{207} \mathrm{~Pb}}{{ }^{235} \mathrm{U}} \\
(6)\end{array}$ & $\begin{array}{c}\frac{{ }^{206} \mathrm{~Pb}}{{ }^{238} \mathrm{U}} \\
(6)\end{array}$ & \\
\hline \multicolumn{12}{|c|}{ Spruce Island Pegmatite [RT-937HA-5] } \\
\hline 1 & $3 \mathrm{gr}, \mathrm{pb}, \mathrm{t}-\mathrm{p}$ & 2 & 218 & 2286 & 5.2 & 0.002 & 5,863 & $0.06119 \pm 0.00004$ & $0.8819 \pm 0.0014$ & $0.10453 \pm 0.00015$ & $646.0 \pm 1.5$ \\
\hline 2 & $1 \mathrm{gr}, \mathrm{pb}, \mathrm{t}-\mathrm{p}$ & 3 & 246 & 2611 & 75.9 & 0.010 & 657.8 & $0.06130 \pm 0.00009$ & $0.8703 \pm 0.0018$ & $0.10296 \pm 0.00016$ & $649.9 \pm 3.3$ \\
\hline \multicolumn{12}{|c|}{ Sedgwick Pluton [RT-93S-17] } \\
\hline 3 & $3 \mathrm{gr}, \mathrm{cl}, \mathrm{c}, \mathrm{l}-\mathrm{p}$ & 10 & 11.6 & 171 & 1.1 & 0.376 & 6,437 & $0.05519 \pm 0.00007$ & $0.5109 \pm 0.0008$ & $0.06715 \pm 0.00007$ & $419.8 \pm 2.8$ \\
\hline 4 & $20 \mathrm{gr}, \mathrm{cl}, \mathrm{c}, \mathrm{l}-\mathrm{p}$ & 69 & 15.6 & 230 & 4.2 & 0.375 & 16,050 & $0.05520 \pm 0.00002$ & $0.5106 \pm 0.0007$ & $0.06710 \pm 0.00009$ & $420.2 \pm 0.9$ \\
\hline 5 & $11 \mathrm{gr}, \mathrm{cl}, \mathrm{c}, \mathrm{l}-\mathrm{p}$ & 33 & 13.3 & 198 & 1.6 & 0.361 & 16,364 & $0.05515 \pm 0.00003$ & $0.5085 \pm 0.0006$ & $0.06687 \pm 0.00007$ & $418.2 \pm 1.3$ \\
\hline \multicolumn{12}{|c|}{ South Penobscot Pluton [S-70-89] } \\
\hline 6 & $1 \mathrm{gr}, \mathrm{pb}, \mathrm{cr}, \mathrm{l}-\mathrm{p}$ & 3 & 139 & 2162 & 6.4 & 0.208 & 4,775 & $0.05522 \pm 0.00006$ & $0.5084 \pm 0.0009$ & $0.06678 \pm 0.00011$ & $421.1 \pm 2.6$ \\
\hline
\end{tabular}

Notes:

(1) All analyses are of zircon. Cardinal number indicates the number of zircon grains analyzed (e.g. 7 grains); all zircon grains were selected from nonparamagnetic separates at $0^{\circ}$ tilt at full magnetic field in Frantz magnetic separator; $\mathrm{c}=$ colorless; $\mathrm{cr}=\mathrm{cracked} ; \mathrm{cl}=\mathrm{clear} ; \mathrm{fl}=\mathrm{flat} ; \mathrm{l}-\mathrm{p}=\mathrm{long}$ prismatic; $p b=$ pale brown; $t-p=$ tips from prisms. All grains air-abraded following Krogh (1982).

(2) $\mathrm{Pb}^{*}=$ radiogenic $\mathrm{Pb}$. Concentrations are known to $\pm 30 \%$ for sample weights of about $30 \mu \mathrm{g}$ and $\pm 50 \%$ for samples $<3 \mu \mathrm{g}$.

(3) Corrected for 0.0125 mole fraction common $-\mathrm{Pb}$ in the ${ }^{205} \mathrm{~Pb}-{ }^{235} \mathrm{U}$ spike.

(4) Calculated $\mathrm{Th} / \mathrm{U}$ ratio assuming that all ${ }^{208} \mathrm{~Pb}$ in excess of blank, common- $\mathrm{Pb}$, and spike is radiogenic $\left(\lambda^{232} \mathrm{Th}=4.9475 \times 10^{-11} \mathrm{y}^{-1}\right)$

(5) Measured, uncorrected ratio.

(6) Ratio corrected for fractionation, spike, blank, and initial common- $\mathrm{Pb}$ (at the determined age from Stacey and $\mathrm{Kramers} 1975$ ). $\mathrm{Pb}$ fractionation correction $=0.094 \% / \mathrm{amu}( \pm 0.025 \%, 1 \sigma)$; U fractionation correction $=0.111 \% / \mathrm{amu}( \pm 0.02 \%, 1 \sigma)$. U blank $=0.2 \mathrm{pg} ; \mathrm{Pb}$ blank $\leq 10 \mathrm{pg}$. Absolute uncertainties $(1 \sigma)$ in the $\mathrm{Pb} / \mathrm{U}$ and ${ }^{207} \mathrm{~Pb} /{ }^{206} \mathrm{~Pb}$ ratios calculated following Ludwig (1980). $\mathrm{U}$ and $\mathrm{Pb}$ half-lives and isotopic abundance ratios from Jaffey et al . (1971). 
a)

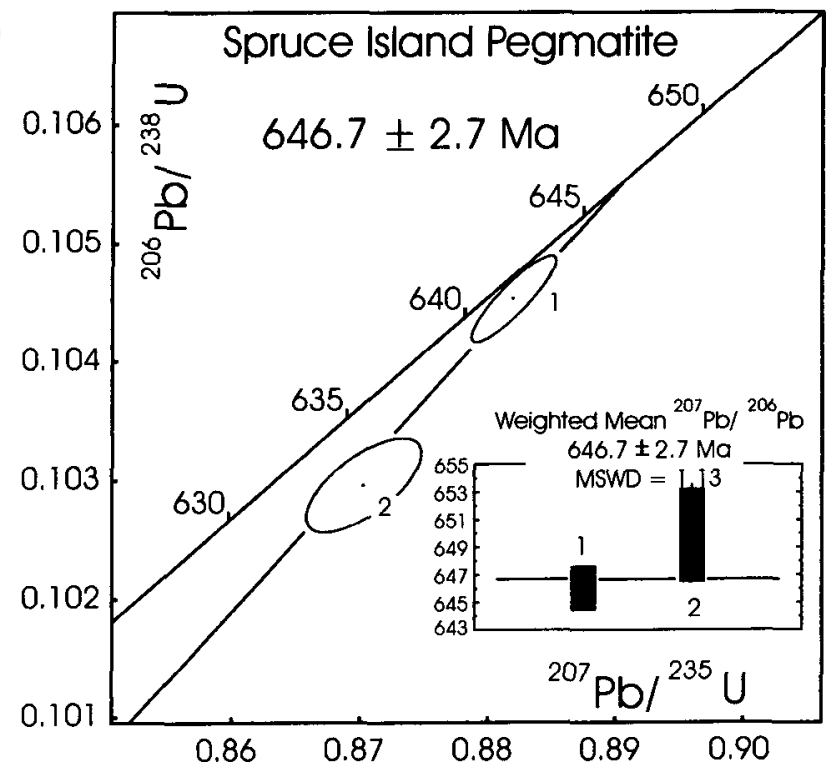

c)

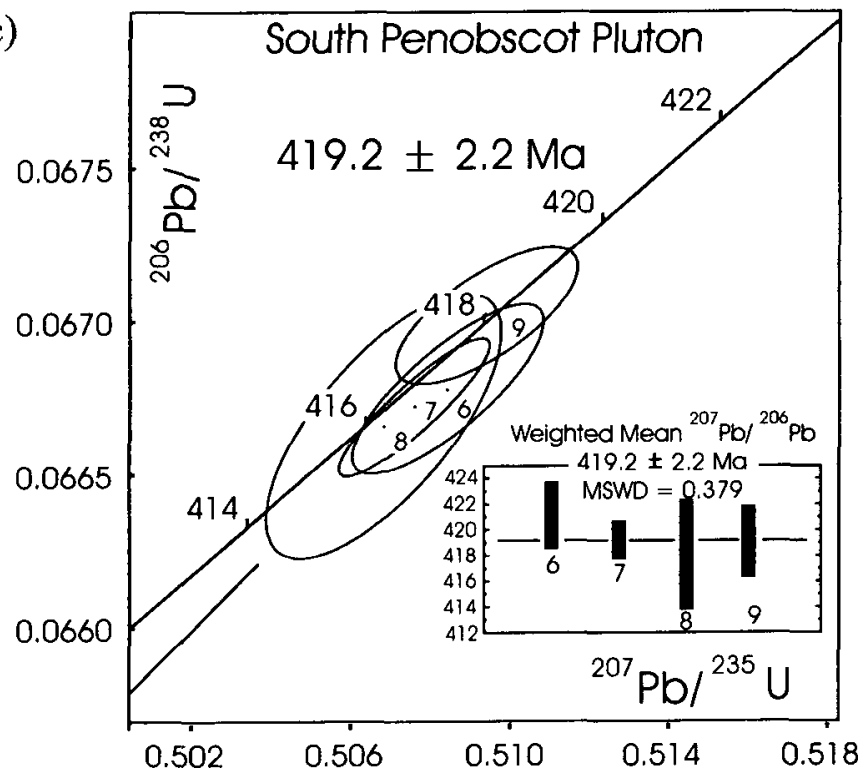

${ }^{40} \mathrm{Ar}{ }^{39} \mathrm{Ar}$ release spectra

Hornblende samples of very high purity weighing about 1 $\mathrm{g}$ and $0.025 \mathrm{~cm}$ to $0.0125 \mathrm{~cm}$ in size were separated from two amphibolite samples from the Seven Hundred Acre Island Formation that were collected at the west side of the south end of Spruce Island (Fig. 2). The suffix $\mathrm{H}$ added to the specimen number indicates that it is a hornblende separate. Sample S8412 is foliated greenish black amphibolite with hornblende crystals up to $3 \mathrm{~mm}$ long. Sample S84-12A was collected about $10 \mathrm{~m}$ from S84-12 and is a greenish black garnet amphibolite with garnet grains up to $3 \mathrm{~mm}$ mostly pseudomorphed by chlorite.

The release spectra for both samples (Table 4 and Figs. $8 \mathrm{a}$ and $8 \mathrm{~b}$ ) are discordant and suggest they have suffered some, albeit minor, ${ }^{40} \mathrm{Ar}$ loss (Harrison and McDougall 1980). Some excess ${ }^{40} \mathrm{Ar}$ is also superimposed on the loss spectra, most b)

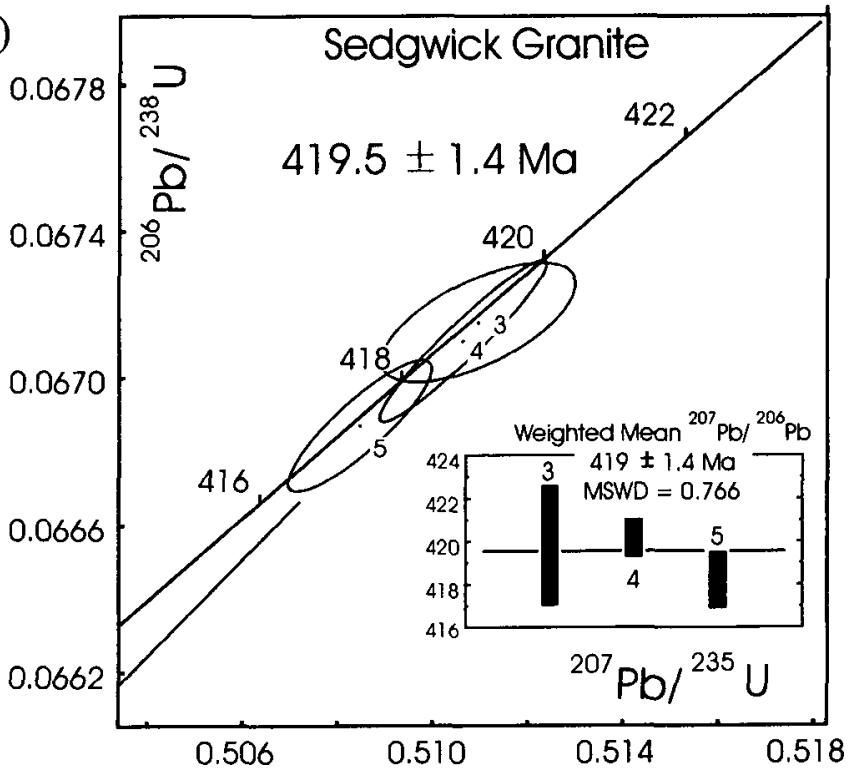

Fig. 7. Concordia diagrams for the $\mathrm{Pb}$ isotopic data from zircons for a) pegmatite at Spruce Island; b) Sedgwick Granite and c) Grey Ridge Granite, South Penobscot Intrusive suite. Data given in Table 2. clearly shown in sample S84-12A-H (Fig. 8b). The uniformity of the $\mathrm{K} / \mathrm{Ca}$ ratio $(0.04$ to 0.05$)$ for the high-temperature steps indicates the high quality of the separates. The two highest temperature steps for sample S84-12-H yield an apparent plateau age of about $669 \mathrm{Ma} \pm 11 \mathrm{Ma}$, and the three highest temperature steps for sample S84-12A-H yield an apparent plateau age about $652 \pm 13 \mathrm{Ma}$. The two ages are indistinguishable within the uncertainty limits and the most straightforward interpretation is that these oldest ages in the loss spectra should approximate the time of cooling through the closure temperature after lower amphibolite facies metamorphism of the Seven Hundred Acre Island Formation. The loss-type spectrum suggests that a later episode of heating caused loss of ${ }^{40} \mathrm{Ar}$ (Harrison and McDougall 1980), possibly the later retrograde lower greenschist metamorphism. 
Table 4. ${ }^{40} \mathrm{Ar} /{ }^{39} \mathrm{Ar}$ analyses for homblendes from amphibolites (moles ${ }^{39} \mathrm{Ar} \times 10^{-14}$ )

\begin{tabular}{|c|c|c|c|c|c|c|c|c|}
\hline $\begin{array}{l}\text { Temp } \\
{ }^{\circ} \mathrm{C}\end{array}$ & $\frac{{ }^{40} \mathrm{Ar}}{{ }^{39} \mathrm{Ar}}$ & $\frac{\frac{37}{\mathrm{Ar}}}{{ }^{39} \mathrm{Ar}}$ & $\frac{\frac{36}{\mathrm{Ar}}}{{ }^{39} \mathrm{Ar}}$ & $\begin{array}{l}\text { Moles } \\
{ }^{39} \mathrm{Ar}\end{array}$ & $\begin{array}{l}{ }^{39} \mathrm{Ar} \\
\% \text { Tot. }\end{array}$ & $\begin{array}{c}\%{ }^{40} \mathrm{Ar} \\
\text { Rad. }\end{array}$ & $\mathrm{K} / \mathrm{Ca}$ & $\begin{array}{l}\text { Apparent } \\
\text { Age (Ma) }\end{array}$ \\
\hline \multicolumn{9}{|c|}{$\mathrm{S} 84-12-\mathrm{H} ; \mathrm{J}$ value $=0.002882$} \\
\hline 750 & 322.8 & 4.683 & 0.6961 & 2.1 & 1.6 & 36.4 & 0.1043 & $528 \pm 23$ \\
\hline 800 & 272.6 & 4.654 & 0.5111 & 2.1 & 1.6 & 44.7 & 0.1049 & $545 \pm 23$ \\
\hline 850 & 271.3 & 3.769 & 0.4370 & 2.7 & 2.0 & 52.5 & 0.1296 & $622 \pm 19$ \\
\hline 900 & 293.4 & 3.303 & 0.5306 & 1.9 & 1.5 & 46.6 & 0.1480 & $601 \pm 22$ \\
\hline 930 & 244.6 & 3.527 & 0.4199 & 3.9 & 2.9 & 49.4 & 0.1386 & $540 \pm 10$ \\
\hline 975 & 334.3 & 9.093 & 0.7779 & 1.5 & 1.1 & 31.4 & 0.0535 & $480 \pm 30$ \\
\hline 985 & 214.6 & 15.590 & 0.3054 & 4.8 & 3.6 & 58.5 & 0.0311 & $563 \pm 15$ \\
\hline 1025 & 170.7 & 10.490 & 0.0937 & 14.4 & 10.8 & 84.3 & 0.0463 & $630 \pm 6$ \\
\hline 1030 & 166.7 & 10.190 & 0.0708 & 20.1 & 15.1 & 87.9 & 0.0477 & $640 \pm 6$ \\
\hline 1045 & 177.2 & 10.540 & 0.1088 & 11.4 & 8.6 & 82.3 & 0.0461 & $637 \pm 7$ \\
\hline 1060 & 207.4 & 10.960 & 0.2099 & 24.6 & 18.5 & 70.5 & 0.0443 & $639 \pm 6$ \\
\hline 1075 & 164.6 & 11.040 & 0.0349 & 28.5 & 21.5 & 94.3 & 0.0440 & $671 \pm 6$ \\
\hline Fuse & 168.2 & 10.830 & 0.0517 & 14.7 & 11.1 & 91.4 & 0.0449 & $666 \pm 6$ \\
\hline \multicolumn{4}{|c|}{ Total gas age } & 132.8 & 100.0 & & & 36 \\
\hline \multicolumn{8}{|c|}{ Highest-temperature plateau age } & $669 \pm 11$ \\
\hline \multicolumn{9}{|c|}{$\mathrm{S} 84-12 \mathrm{~A}-\mathrm{H} ; \mathrm{J}$ value $=0.002924$} \\
\hline 880 & 373.7 & 3.009 & 0.6499 & 3.3 & 1.9 & 48.7 & 0.1625 & $771 \pm 14$ \\
\hline 930 & 286.4 & 2.206 & 0.5073 & 4.2 & 2.5 & 47.7 & 0.2218 & $607 \pm 8$ \\
\hline 975 & 211.9 & 4.238 & 0.3277 & 6.0 & 3.5 & 54.4 & 0.1153 & $526 \pm 12$ \\
\hline 990 & 226.1 & 6.768 & 0.3839 & 4.5 & 2.6 & 50.1 & 0.0720 & $518 \pm 8$ \\
\hline 1010 & 206.3 & 9.324 & 0.2704 & 6.6 & 3.9 & 61.6 & 0.0522 & $574 \pm 9$ \\
\hline 1025 & 170.2 & 10.680 & 0.1068 & 15.3 & 8.9 & 81.9 & 0.0455 & $621 \pm 5$ \\
\hline 1040 & 177.7 & 11.090 & 0.1195 & 11.4 & 6.7 & 80.6 & 0.0438 & $636 \pm 6$ \\
\hline 1050 & 179.5 & 11.260 & 0.1200 & 11.7 & 6.8 & 80.7 & 0.0431 & $642 \pm 6$ \\
\hline 1060 & 181.2 & 11.670 & 0.1317 & 12.6 & 7.4 & 79.0 & 0.0416 & $636 \pm 7$ \\
\hline 1080 & 177.0 & 11.780 & 0.1248 & 24.3 & 14.2 & 79.7 & 0.0412 & $628 \pm 6$ \\
\hline 1100 & 166.2 & 11.890 & 0.0690 & 21.6 & 12.6 & 88.3 & 0.0408 & $649 \pm 6$ \\
\hline 1125 & 162.6 & 11.870 & 0.0567 & 26.7 & 15.6 & 90.3 & 0.0409 & $649 \pm 6$ \\
\hline Fuse & 163.9 & 11.760 & 0.0534 & 22.8 & 13.3 & 90.9 & 0.0413 & $657 \pm 7$ \\
\hline \multicolumn{4}{|c|}{ Total gas age } & 171.0 & 100.0 & & & 633 \\
\hline \multicolumn{8}{|c|}{ Highest-temperature plateau age } & $652 \pm 13$ \\
\hline
\end{tabular}

\section{TECTONIC SETTING OF THE ISLESBORO BLOCK}

The data given here for the lithostratigraphy, geochemistry, geochronology, and metamorphic petrology for the Islesboro block augment earlier discussions of the tectonic history of the peri-Gondwanan terranes in the Penobscot Bay region by Stewart et al. (1995b), and by Stewart (1998).

Implied basement beneath the Seven Hundred Acre Island Formation is continental but of unknown age. The nature of continental crust related to the Islesboro block is unclear as neither Laurentian nor classical Avalonian basement sensu stricto is exposed in coastal Maine. The $\mathrm{Pb}$ isotopes of the Grenville massifs from Vermont (R. Ayuso and N. Ratcliffe, unpublished data) and from Ontario (Fig. 6) have lower values of ${ }^{207} \mathrm{~Pb} /{ }^{204} \mathrm{~Pb}$ (DeWolfe and Mezger 1994) than most of the more radiogenic rocks from the Islesboro block. The agecorrected isotopic differences for the estimated initial values (at $647 \mathrm{Ma}$ ) in the amphibolite and schist samples from the Seven Hundred Acre Island Formation and for Grenville gneisses show that the Grenville massifs cannot be the radiogenic source controlling the high ${ }^{207} \mathrm{~Pb}^{1204} \mathrm{~Pb}$ values.

The nearest exposed Proterozoic basement is periGondwanan and located in New Brunswick. In contrast to the Grenville massifs, the majority of basement rocks from periGondwanan rocks and the Avalonian zone in the northern Appalachian orogen (Fig. 6) have radiogenic $\mathrm{Pb}$ (Ayuso and Bevier 1991; Ayuso et al. 1996; Ayuso and Arth 1997; Whalen et al. 1994a, 1994b, 1996a, 1996b; Ayuso 1999) such
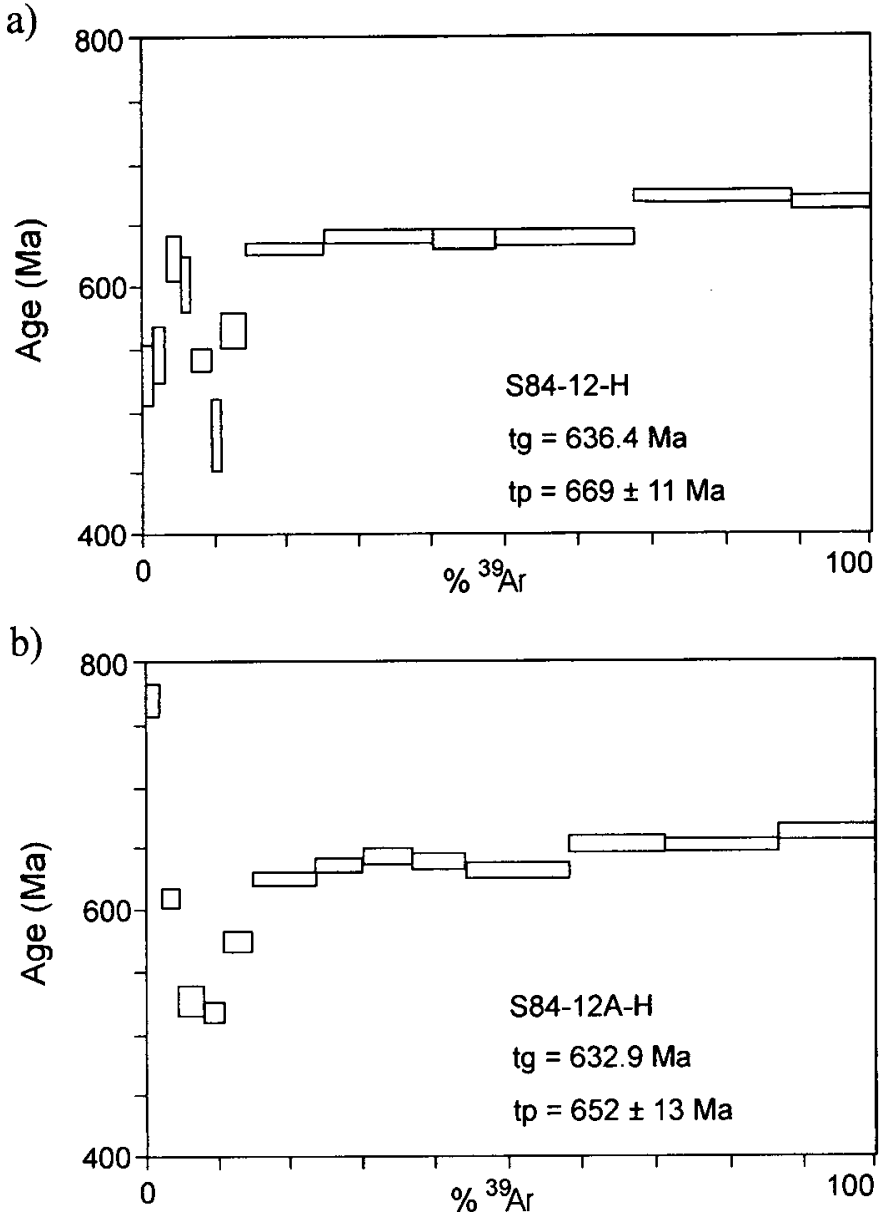

Fig. $8{ }^{40} \mathrm{Ar} /{ }^{39} \mathrm{Ar}$ release spectra for homblende from amphibolite samples a) S84-12-H and b) S84-12A-H. $\mathrm{Tg}=$ total gas age; $\mathrm{Tp}=$ high temperature plateau age. Data given in Table 4 .

as that required for the rocks from the Seven Hundred Acre Island Formation. Moreover, Paleozoic granitic rocks in this area are known to have incorporated evolved radiogenic crustal reservoirs, as suggested by $\varepsilon \mathrm{Nd}$ values as low as about -3.0 and $\mathrm{T}_{\mathrm{DM}}$ values as old as about $2 \mathrm{Ga}$ (Arth and Ayuso 1993; R. Ayuso unpublished data), and ${ }^{207} \mathrm{~Pb}^{1204} \mathrm{~Pb}>\sim 15.6$ (Ayuso and Bevier 1991; Whalen et al. 1996a, b).

The protoliths of the Seven Hundred Acre Island Formation include mature quartz arenite, aluminous pelite, and dolomitic carbonate sediments that were deposited on a mature continental platform in the Late Proterozoic. The chondrite-normalized diagrams show that the schists are LREE-enriched and the HREE patterns are virtually flat. The $\mathrm{Pb}$ isotopic compositions of the whole rocks are more radiogenic than the average $\mathrm{Pb}$ crustal evolution curve (Stacey and Kramers 1975), and attest to their origin in evolved crustal isotopic reservoirs. The age of the Seven Hundred Acre Island Formation is probably Neoproterozoic, although not accurately known.

The continental crust was attenuated and the sediments upon it were intruded by sub-alkaline to alkaline basaltic rocks that were the protoliths of the amphibolite units studied. Immobile trace elements (Figs. 3, 4) and their ratios (Fig. 5) 
allow inferences about the nature of the sources and tectonic settings. The amphibolite samples have flat REE patterns and show no evidence of fractionation of $\mathrm{Eu}$ by plagioclase or garnet. They are not related to arc sources as demonstrated by high abundances of $\mathrm{Ti}$ and $\mathrm{Y}$, by low $\mathrm{Th}$, and importantly, because they lack significant negative $\mathrm{Nb}$ (and $\mathrm{Ta}$ ) anomalies with respect to $\mathrm{Th}$ and Ce (Pearce 1996). In general, the amphibolites have normalized patterns with negative slopes, $\mathrm{Zr}$ - and Ti-enrichment relative to $\mathrm{MORB}$, and $\mathrm{Y}, \mathrm{Yb}$, and $\mathrm{Sc}$ values similar to MORB. These features are consistent with the involvement of MORB-type source regions. However, the high overall abundances of the REE and high field-strength elements compared to MORB and volcanic-arc basalts point to a predominant origin from an incompatible element-enriched (e.g., E-MORB) source or within-plate basalt-type source region (Fig. 5). The relative abundances of $\mathrm{Y}, \mathrm{Yb}$, and $\mathrm{Sc}$ are unlike those of typical within-plate basalts (typically depleted relative to MORB). Values of $\mathrm{Ti} / \mathrm{Y}>100$ indicate that garnet was not in equilibrium with magmas represented by the amphibolite samples and attest to the contribution of deeper $(>50 \mathrm{~km})$ source regions as required for within-plate basalts. Thus, the amphibolite samples have geochemical variations and normalized patterns that are intermediate between tholeiitic and within-plate basalt end members consistent with derivation in a transitional setting where E-MORB magmas predominated and continental crust was under extension. The $\mathrm{Pb}$ isotopic compositions of the amphibolites are radiogenic and more similar to ratios observed in peri-Gondwanan basements in Atlantic Canada than in Grenville basement (Fig. 6).

The Seven Hundred Acre Island Formation was deformed and metamorphosed to lower amphibolite facies at about 670 to $650 \mathrm{Ma}$ before it was intruded by the granitic pegmatite from which the zircon that was dated at $647 \pm 2.7 \mathrm{Ma}$ was obtained.

Late in the Proterozoic or early in the Cambrian the Islesboro Formation was deposited unconformably upon the Seven Hundred Acre Island Formation in an environment where a stable continental platform yielded clean quartz arenite, conglomerate, pelitic sand, and dolomitic limestone. There likely was a nearby volcanic source for volcanic-rich sediments in the Islesboro Formation. The Islesboro Formation was metamorphosed to lower greenschist facies, possibly at the same time that the underlying metamorphic rocks of the Seven Hundred Acre Island Formation were retrograded. This metamorphism may have been late in the Cambrian when the Ellsworth Schist was metamorphosed, but this hypothesis is speculative.

\section{REGIONAL SIGNIFICANCE}

The various peri-Gondwanan terranes were agglomerated into a composite terrane by a complex and incompletely known series of tectonic events between the Cambrian and the Silurian. This problem is especially difficult to decipher for coastal Maine and along strike to the northeast in New Brunswick (Stewart 1998; Fyffe et al. 1999, p. 77-81), and is being solved incrementally by new mapping (Johnson 2001), discoveries of fossils (e.g. Fyffe and Riva 2001) and new results from $\mathrm{Pb}$-zircon isotopic geochronology. The discussion that follows is focused on the region just described, but we have tried to make it consistent with what we understand about the tectonic history of southern New Brunswick.

Barr and White (1996) critically evaluated the tectonic and magmatic history of the many peri-Gondwanan as well as the Avalonian sensu stricto terranes in New Brunswick and Nova Scotia and concluded that peri-Gondwanan terranes there had basements up to $\sim 200 \mathrm{Ma}$ older than the Avalonian terranes sensu stricto and had different magmatic histories and different stratigraphic sequences in their lower Paleozoic cover sequences. They suggested that the suite of periGondwanan terranes in Atlantic Canada comprised a tectonic agglomeration of terranes, possibly the equivalent of a Wilson cycle along the southeastern shore of the Iapetus Ocean and that may have acted as a buffer zone between the Avalon composite terrane and Laurentia during Silurian and Devonian continental collision. Cocks et al. (1997) discussed the agglomeration of different terranes along large continuous strike-slip motions during the late Proterozoic and early Paleozoic and tried to define as much of the history of these processes as they could using paleontological data for control. Johnson and McLeod (1996) describe highly faulted rocks in the New River belt of southern New Brunswick where Neoproterozoic granitoid rocks and volcanic rocks have lower Paleozoic cover sequences with some lithologic and chronological similarities to formations found in the Penobscot Bay region. Many papers like these describe the agglomeration and subsequent structural history of Avalonian and peri-Gondwanan composite terranes but we will consider only those aspects of the process we observe in northern Penobscot Bay, which seem to affect only peri-Gondwanan terranes.

The well-sorted and clean platformal lithologies in the Islesboro block are similar to some rocks found in the lower part of the stratigraphic section in the St. Croix terrane (Fig. 1) exposed west of the Turtle Head fault zone. Berry and Osberg (2000) and Berry et al. (2000) have suggested that they may be correlative. However, unlike the lower greenschist rocks of the Islesboro Formation the rocks west of Penobscot Bay are metamorphosed to upper amphibolite facies and overlain by rusty black schist of Late Cambrian and Ordovician age that has not been found in the Islesboro block.

The oldest principal fault in the northern Penobscot Bay region (Fig. 1) is the Sennebec Pond thrust fault, which separates the peri-Gondwanan St. Croix terrane on the east from the peri-Gondwanan Fredericton trough terrane on the west. The age of folding and metamorphism of the St. Croix terrane must be either Ordovician or Early Silurian because the undeformed and unmetamorphosed Late Silurian Northport. Granite and Youngtown Granite intrude metamorphosed rocks of the St. Croix terrane. Metamorphism of the rocks of the Fredericton trough terrane occurred before first motion on the Sennebec Pond fault because this fault separates lower and middle amphibolite facies rocks of the Fredericton trough west of Belfast. In places along the fault, metamorphosed rocks from both terranes are milled together and contain shear bands and asymmetric folds consistent with 
dextral shear (Stewart et al. 1995, p. 45). The emplacement of the Sennebec Pond thrust fault and regional metamorphism of the adjacent terranes all may be of Silurian age. West $e t$ al. (1992) dated the Late Silurian (423 $\pm 3 \mathrm{Ma}$ ) Pocomoonshine pluton in eastern Maine and they interpreted it to intrude across a fault equivalent to the Sennebec Pond fault. This provides an upper constraint on the age of the Sennebec Pond fault.

After the emplacement of the St. Croix terrane, prominent younger strike-slip zones in the Silurian juxtaposed the periGondwanan Ellsworth terrane and the smaller Islesboro block (Fig. 1). The older of these strike-slip zones, the inferred Penobscot Bay fault zone and its related splays, the Smith Cove and North Blue Hill faults, juxtaposed the Ellsworth terrane and the St. Croix terrane. In southern Islesboro, blocks of the mafic metavolcanic rocks of the North Haven Greenstone of the Ellsworth terrane were shuffled along strike-slip faults with blocks of the Islesboro terrane as the Islesboro block as a whole was moved northeastward between the Ellsworth and St. Croix terranes. About $10 \mathrm{~km}$ southeast of the present trace of the Penobscot Bay fault zone at Ames Knob in North Haven, Llandoverian fossils of periGondwanan affinity occur above an unconformity on North Haven Greenstone (Smith et al. 1907; Brookins et al. 1973; Berry and Boucot 1970; Gates 2001). The Penobscot BaySmith Cove fault cuts the contact metamorphic aureole around the $419.5 \pm 1 \mathrm{Ma}$ Sedgwick pluton (Fig. 7b). When movement on this fault zone was impeded by the emplacement of the South Penobscot Intrusive Suite the locus of right lateral strike-slip faulting shifted northward along other fault splays and isograds around the South Penobscot Intrusive Suite were displaced eastward. Continued strike-slip faulting was interrupted and the fault zone was re-established northwestward until it was replaced by the Turtle Head fault zone, which bounds the western side of the Islesboro block. The Turtle Head fault zone cuts the northern end of the South Penobscot Intrusive Suite, which was dated at $419.2 \pm 2.2 \mathrm{Ma}$ (Fig. 7c).

The Turtle Head fault strike-slip zone separates the greenschist facies rocks of the Islesboro block from the middle amphibolite facies regional metamorphic rocks of the St. Croix terrane, which were still above hornblende and biotite closure temperatures when fault motion occurred (West $e t$ al. 1995). However, no evidence of increased regional metamorphic grade has been observed in the Islesboro Formation east of the Turtle Head fault. The Turtle Head fault zone is intruded by the Lucerne Granite ( $380 \pm 4 \mathrm{Ma}$, Zartman and Gallego 1979) and subsequent geologic events have not significantly changed the relationships. Later events include the attachment of the peri-Gondwanan and Avalonian composite terranes to Laurentia and several orogenic episodes in the Late Paleozoic that led to the formation of the Appalachian Mountains and in the Mesozoic that led to the formation of the Atlantic Ocean.

\section{ACKNOWLEDGEMENTS}

Stewart acknowledges the principal roles of Paul C. Bateman and Harvey E. Belkin in the mapping of Islesboro in the summer of 1968 and assistance in the laboratory by Marta J.K. Flohr, J.J. McGee, Jane Hammarstrom, David West, and others. Many geologists have visited the islands with Stewart over the years and offered valuable suggestions and comments. In October 1985, P.H. Osberg accompanied Stewart while outcrops in and near Gilkey Harbour were remapped and he has been a valuable source of ideas about the regional geology of the Islesboro block. David Weary and Jean Self-Trail prepared digital versions of Figs. 1 and 2 . Reviews by Peter Lyttle, G.R. Robinson, and by journal reviewers Henry N. Berry IV and Brent V. Miller considerably improved this paper. David McMullin greatly facilitated publication of the figures and tables.

\section{REFERENCES}

ARTH, J.G., \& AYUSO, R.A., 1993. Nd isotopic composition of Acadian plutons from northern New England. Geological Society of America, Abstracts with Progams, 25, p. A-41.

AYUSO, R.A. 1999. Geochemical and metallogenic contrasts in Paleozoic granitic rocks of the northern New England Appalachians. In Norumbega fault system of the Northern Appalachians. Edited by A. Ludman and D.P. West. Geological Society of America, Special Paper 331, pp. 121-154.

AYUSO, R.A., \& ARTH, J.G. 1997. The Spruce Head composite pluton: an example of mafic to silicic Silurian magmatism in coastal Maine, northern Appalachians. In The Nature of Magmatism in the Appalachian Orogen Edited by A.K. Sinha, J.B. Whalen, and J.P. Hogan. Geological Society of America, Memoir 191, pp. $19-44$.

AYUSO, R.A., \& BEVIER, M.L. 1991. Regional differences in $\mathrm{Pb}$ isotopic compositions of feldspars in plutonic rocks of the northern Appalachian Mountains, USA and Canada: a geochemical method of terrane correlation. Tectonics, 10, pp. 191-212.

AYUSO, R.A., BARR, S.M., \& LONGSTAFFE, F.J. 1996. Pb and O isotopic constraints on the source of granitic rocks from Cape Breton Island, Nova Scotia, Canada. American Journal of Science, 296, pp. 789-817.

BAEDECKER, P.A. 1987. Methods for geochemical analysis. U.S. Geological Survey Bulletin 1770, 132 p.

BARR, S.M., \& WhITE, C.E. 1996. Contrasts in late Precambrian early Paleozoic tectonothermal history between Avalon composite terrane sensu stricto and other possible periGondwanan terranes in southern New Brunswick and Cape Breton Island, Canada. In Avalonian and Related periGondwanan Terranes of the Circum-North Atlantic. Edited by R.D. Nance and M.D. Thompson. Geological Society of America, Special Paper 304, pp. 95-108.

BerRY, H.N., IV, \& OSBERG, P.H. 2000. The Megunticook Formation. In Guidebook for field trips in Coastal and EastCentral Maine, New England Intercollegiate Geological Conference, 92nd Annual Meeting, Oct. 6-8, 2000, Orono, Maine. Edited by M.G. Yates, D.R. Lux, and J.T. Kelley. University of Maine, Orono, pp. 54-70.

Berry, H.N., IV, SChOONMAKer, A., \& GuidotTI, C.V. 2000. The Benner Hill Sequence. In Guidebook for field trips in Coastal and East-Central Maine, New England Intercollegiate Geological Conference, 92nd Annual Meeting, Oct. 6-8, 2000, 
Orono, Maine. Edited by M.G. Yates, D.R. Lux, and J.T. Kelley. University of Maine, Orono, pp. 187-207.

BERRY, W.B.N., \& BOUCOT, A.J. 1970. Correlation of the North American Silurian rocks. Geological Society of America, Special Paper 102, 289 p.

BROOKINS, D.G. 1976. Geochronological contributions to stratigraphic interpretation and correlation in the Penobscot Bay area, eastern Maine. In Contributions to the stratigraphy of New England. Edited by L.R. Page. Geological Society of America, Memoir 148, pp. 129-145.

BROOKINS, D.G., BERDAN, J.M., \& STEWART, D.B. 1973. Isotopic and paleontological evidence for correlating three volcanic sequences in the Maine coastal volcanic belt. Geological Society of America Bulletin, 84, pp. 1619-1628.

COCKS, L.R.M., MCKerRow, W.S., \& VAN StaAl, C.R. 1997. The margins of Avalonia, Geological Magazine, 134, pp. 626-636.

DEWOLF, C.P., \& MEZGER, K. 1994. Lead isotope analyses of leached feldspars: Constraints on the early crustal history of the Grenville Orogen. Geochimica et Cosmochimica Acta, 58, pp. 5537-5550.

FYFFE, L.R., \& RIVA, J.F.V. 2001. Regional significance of graptolites from the Didgequash Formation of southwestern New Brunswick. In Current Research 2000. Edited by B.M.W. Carroll, New Brunswick Department of Natural History and Energy, Minerals and Energy Division, Mineral Resource Report 2001-4, pp. 47-54.

FYFFE, L.R., PICKERILl, R.K., \& STRINGER, P 1999. Stratigraphy, sedimentology and structure of the Oak Bay and Waweig formations, Mascarene Basin: implications for the paleotectonic evolution of southwestern New Brunswick. Atlantic Geology, 35, pp. 55-84.

GATES, O. 2001. Bedrock Geology of North Haven and Vinalhaven Islands. Maine Geological Survey, Open-file No. 01-373, 28 p.

GREGG, W.J. 1985. Microscopic deformation mechanisms associated with mica film formation in cleaved psammitic rocks. Journal of Structural Geology, 7, pp. 45-56.

GREGG, W.J. 1986. Deformation of chlorite-mica aggregates in cleaved psammitic and pelitic rocks from Islesboro, Maine, U.S.A. Journal of Structural Geology, 8, pp. 59-68.

HARRISON, T.M. \& MCDOUGALL, I. 1980. Investigations of an intrusive contact, northwest Nelson, New Zealand-II. Diffusion of radiogenic and excess ${ }^{40} \mathrm{Ar}$ in hornblende revealed by ${ }^{40} \mathrm{Ar} /{ }^{39} \mathrm{Ar}$ age spectrum analysis. Geochemica et Cosmochimica Acta, 44, pp. 2005-2020.

JAFFEY, A.F., FLYNN, K.F., GLENDENIN, L.E., \& ESSLING, A.M. 1971. Precision measurements of half-lives and specific activities of ${ }^{235} \mathrm{U}$ and ${ }^{238} \mathrm{U}$. Physics Review Section C, Nuclear Physics, 4, pp. 1889-1906.

JOHNSON, S.H. 2001. Stratigraphy of Neoproterozoic and Devonian Carboniferous volcanic and epiclastic rocks in the Long Reach and Taylor's Island areas, New Brunswick. In Guidebook to field trips in New Brunswick and western Maine, New England Intercollegiate Geological Conference, 93 ${ }^{\text {rd }}$ Annual Meeting, September 21-23, 2001, Fredericton, New Brunswick. Edited by R.K. Pickerill and D.K. Lentz. University of New Brunswick, pp. A2-1 - A2-15.

JoHnSON, S.C., \& MCLEOD, M.J. 1996. The New River Belt: A unique segment along the western margin of the Avalon composite terrane, southern New Brunswick, Canada. In Avalonian and Related Peri-Gondwanan terranes of the CircumNorth Atlantic. Edited by R.D. Nance and M.D. Thompson. Geological Society of America, Special Paper 304, pp. 149-164.

KROGH, T.E. 1973. A low contamination method for hydrothermal decomposition of zircon and extraction of $\mathrm{U}$ and $\mathrm{Pb}$ for isotopic determination. Geochimica et Cosmochimica Acta, 37, pp. 485494.
KROGH, T.E. 1982. Improved accuracy of U-Pb zircon dating by the creation of more concordant systems using air abrasion technique. Geochimica et Cosmochimica acta, 46, pp. 637-649.

LUDWIG, K.R. 1980. Calculation of uncertainties of U-Pb isotope data. Earth and Planetary Science Letters, 46, pp. 212-220.

LUDWIG, K.R. 1992. ISOPLOT: A plotting and regression program for radiogenic-isotope data, version 2.57. U.S. Geological Survey Open File Report, 91-445, 40 p.

LuX, D.R. 1986. ${ }^{40} \mathrm{Ar} /{ }^{39} \mathrm{Ar}$ ages for minerals from the amphibolite dynamothermal aureole, Mont Albert, Gaspé, Québec. Canadian Journal of Earth Sciences, 23, pp. 21-26.

PEARCE, J.A. 1996. A user's guide to basalt discrimination diagrams. In Trace element geochemistry of volcanic rocks: Applications for massive sulphide exploration. Edited by D.A. Wyman. Geological Association of Canada, Short course notes 12, pp. 79-114.

PEARCE, J.A., \& NoRRY, M.J. 1979. Petrogenetic implications for Ti, $\mathrm{Zr}, \mathrm{Y}$, and $\mathrm{Nb}$ variations in volcanic rocks. Contributions to Mineralogy and Petrology, 69, pp. 33-47.

PEARCE, J.A., HaRris, N.B.W., \& TindLE, A.W. 1984. Trace element discrimination diagrams for the tectonic interpretation of granitic rocks. Journal of Petrology, 25, pp. 956-983.

PlumB, K.A. 1991. New Precambrian time scale. Episodes, 14, no. 2, pp. 139-140.

Smith, G.O., BAstin, E.S., \& BROWN, C.W. 1907. Description of the Penobscot Bay quadrangle, Maine. U.S. Geological Survey Geologic Atlas, Folio 149, 14 p., scale: 1:125,000.

STACEY, J.S., \& KRAMERS, J.D. 1975. Approximation of terrestrial lead isotope evolution by a two-stage model. Earth and Planetary Science Letters, 26, pp. 207-221.

STEIGER, R.H., \& JAGER, E. 1977. Subcommission on Geochronology: Convention of the use of decay constants in geo- and cosmochronology. Earth and Planetary Science Letters, 36, pp. $359-362$.

STEWART, D.B. 1974. Precambrian rocks of Seven Hundred Acre Island and development of cleavage in the Islesboro Formation. In Guidebook for field trips in east-central and north-central Maine, New England Intercollegiate Geological Conference, $66^{\text {th }}$ Annual Meeting, October 12-13, 1994, Orono, Maine. Edited by P.H. Osberg. University of Maine, Orono, pp. 86-98.

StewarT, D.B. 1998. Geology of northern Penobscot Bay, Maine, with contributions to geochronology by Robert D. Tucker, U.S. Geological Survey Miscellaneous Investigations Series Map I2551, 2 sheets, scale 1:62,500.

STEWART, D.B., \& LUX, D.R. 1988. Lithologies and metamorphic age of the Precambrian rocks of Seven Hundred Acre Island and vicinity, Penobscot Bay, Maine. Geological Society of America, Abstracts with Programs, 20, p. 73.

STEWART, D.B., ARTH, J.G., \& FlOHR, M.J.K. 1988. Petrogenesis of the South Penobscot Intrusive Suite, Maine. American Journal of Science, 288-A, pp. 75-114.

Stewart, D.B., Wright, B.E., Unger, J.D., PhILliPS, J.D., \& HUTCHINSON, D.R. 1993. Global geoscience transect 8; QuebecMaine-Gulf of Maine transect, southeastern Canada, northeastern United States of America. U.S. Geological Survey Miscellaneous Investigations Series Map 1-2329, scale 1:1,000,000.

Stewart, D.B., Tucker, R. D., \& West, D. P., JR. 1995a. Genesis of Silurian composite terrane in northern Penobscot Bay. In Guidebook for field trips in southern Maine and adjacent New Hampshire, New England Intercollegiate Geological Conference, 87 $7^{\text {th }}$ Annual Meeting, Oct. 6-8, 1995, Brunswick, Maine. Edited by A.M. Hussey II and R. Johnston. Bowdoin College, Brunswick, Maine, pp. A3-1- A3-21.

StewART, D.B., UNGer, J.D., \& HutChinson, D.R. 1995b. Silurian tectonic history of Penobscot Bay region, Maine. Atlantic 
Geology, 31, pp. 67-79.

STEWART, D.B., TUCKer, R.D., AyUSO, R.A., \& LUX, D.R. 1998. Tectonic setting of the Islesboro Terrane and a minimum age of the Seven Hundred Acre Island Formation, the oldest rocks in Maine, Geological Society of America, Abstracts with Programs, 30, p. 76.

TUCKER, R.D., \& MCKERROW, W.S. 1995. Early Paleozoic chronology: a review in light of new $\mathrm{U}-\mathrm{Pb}$ zircon ages from Newfoundland and Britain. Canadian Journal of Earth Sciences, 32, pp. 368-379.

TuCKer, R.D., Bradley, D.C., Ver Straeten, C.A., Harris, A.G., EBERT, J.R., \& MCCUTCHEON, S.R. 1998. New U-Pb zircon ages and the duration and division of Devonian time. Earth and Planetary Science Letters, 158, pp. 175-186.

TUCKER, R.D., OSBERG, P.H., \& BERRY, H.N., IV 2001. The geology of a part of Acadia and the nature of the Acadian Orogeny across central and eastern Maine. American Journal of Science, 301, pp. 205-260.

WeST, D.P., JR., LuDMAN, A, \& Lux, D.R. 1992. Silurian age for the Pocomoonshine gabbro-diorite, southeastern Maine, and its regional tectonic implications. American Journal of Science, 292 , pp. 253-273.

WeSt, D.P., JR., GuidotTI, C.V., \& LUX, D.R. 1995. Silurian orogenesis in the western Penobscot Bay region, Maine. Canadian Journal of Earth Sciences, 32, pp. 1845-1858.

Whalen, J.B., JenNer, G.A., CURRIE, K.L., BARR, S.M., LONGSTAFFE, F.J., \& HeGNER, E. 1994a. Geochemical and isotopic characteristics of granitoids of the Avalon zone, southern New Brunswick: Possible evidence for repeated delamination events. Joumal of Geology, 102, pp. 269-282.

WhALEN, J.B., JENNER, G.A., \& HEGNER, E. 1994b. Geochemical and isotopic ( $\mathrm{Nd}, \mathrm{O}$, and $\mathrm{Pb}$ ) constraints on granite sources in the Humber and Dunnage zones, Gaspé, Québec, and New Brunswick: implications for tectonics and crustal structure. Canadian Journal of Earth Sciences, 33, pp. 129-139.

WHALEN, J.B., FYFFE, L.R., LONGSTAFFE, F.J., \& JENNER, G.A. 1996a The position and nature of the Gander-Avalon boundary, southem New Brunswick, based on geochemical and isotopic data from granitoid rocks. Canadian Journal of Earth Sciences, 33, pp. 129-139.

Whalen, J.B., JenNer, G.A., LONGSTAFfe, F.J., \& Hegner, E. 1996 b. Nature and evolution of the eastern margin of Iapetus: geochemical and isotopic constraints from Siluro-Devonian granitoid plutons in the New Brunswick Appalachians. Canadian Journal of Earth Sciences, 33, pp. 140-155.

WooD, D.A. 1980. The application of a Th-Hf-Ta diagram to problems of tectonomagmatic classification and to establishing the nature of crustal contamination of basaltic lavas of the British Tertiary Volcanic Province. Earth and Planetary Science Letters, v. 50, pp. 11-30.

ZARTMAN, R.E., \& GALLEGO, M.D. 1979. USGS(D)-BUB-8 (Sample 139), USGS(D)-BUB-9 (Sample 140), USGS(D)-BUB-10 (Sample 141), and USGS(D)-ORA-301 (Sample 142). In Radiometric ages; compilation B. Edited by R.F. Marvin and S.W. Dobson. U.S. Geological Survey. Isochron/West, no. 26, pp. 18-29.

Editorial responsibility: Sandra M. Barr

\section{APPENDIX A}

Localities for samples (Fig. 2), and descriptions for samples listed in Table 1. Abbreviations are as follows: Ab, albite; Act, actinolite; And, andalusite; $\mathrm{Bi}$, biotite; $\mathrm{Ca}$, calcite; $\mathrm{Ch}$, chlorite; Ctd, chloritoid; Ep, epidote; $\mathrm{Ga}$, garnet; $\mathrm{Hb}$, hornblende; Il, ilmenite; Mag, magnetite; Mu, muscovite; Or, orthoclase; Qu, quartz; St, staurolite; Ti, titanite; Zo, zoisite.

\section{Amphibolite and hornblende gneiss}

S84-3: Coarse amphibolite, southwestern coast of Lime Island. Mode: $\mathrm{Hb} 15 \%$, Act 25\%, Ch 25\%, Ab 15\%, Ep 10\%, Qu 5\%, Il $3 \%$, Mag $2 \%$.

Sample used for determination of whole rock $\mathrm{Pb}$ isotopes.

S84-12: Amphibolite, west side of Spruce Island at southwestern end.

Mode: $\mathrm{Hb} 70 \%$, Ab 10\%, Act 5\%, Qu 5\%, Ti 5\%, Ch $2 \%$, Mu $2 \%$, Ap $1 \%$.

Sample used for detrmination of whole rock $\mathrm{Pb}$ isotopes. Hornblende separate used for ${ }^{40} \mathrm{Ar} /{ }^{39} \mathrm{Ar}$ release spectra.

S84-12A: Garnet amphibolite, $10 \mathrm{~m}$ from site of S84-12, west side of Spruce island at southwestern end.

Mode: $\mathrm{Hb} 70 \%$, Qu $10 \%$, Ch $10 \%$, Ga $5 \%$, Ti 3\%, Ep 2\%, traces of Ap and Il.

Sample used for determination of whole rock $\mathrm{Pb}$ isotopes. Hornblende separate used for ${ }^{40} \mathrm{Ar} /{ }^{39} \mathrm{Ar}$ release spectra.

S84-13: Amphibolite, northernmost point of Spruce Island. Mode: $\mathrm{Hb} 35 \%$, Act 10\%, Ab 40\%, Ep 5\%, Ch 5\%, Ti 3\%, Mag 2\%.

S84-19: Amphibolite from deformed dike in marble, southwestern point on Lime Island.

Mode: $\mathrm{Hb} 25 \%$, Act 30\%, Ab 25\%, Zo 15\%, Ch 3\%, Mag 2\%. Sample used for determination of whole rock $\mathrm{Pb}$ isotopes.

S68-175: Hornblende-rich gneiss, middle of east side of Spruce Island.

Mode: $\mathrm{Hb} 90 \%$, Ep $8 \%$, Ch $2 \%$, traces of Mag.

Sample used for determination of whole rock $\mathrm{Pb}$ isotopes.

\section{Schist and gneiss}

S68-65: Garnet-muscovite-andalusite-staurolite schist, west of boat landing, Cradle Cove, Seven Hundred Acre Island.

Mode: Ga $30 \% \%$, Mu $30 \%$, Qu $30 \%$, And $5 \%$, St $2 \%$, Ctd $2 \%$, traces of zircon, rutile and pyrrhotite.

Sample used for determination of whole rock $\mathrm{Pb}$ isotopes.

S68-177: Splendent garnet gneiss, southern end of Spruce Island.

Mode: Mu 62\%, Qu 25\%, Ga 5\%, Ch 2\%, And 2\%, Mag $1 \%$. Sample used for determination of whole rock $\mathrm{Pb}$ isotopes.

S84-23: Splendent muscovite schist, small cove off east side of Seal Cove, west of road. 
Mode: Mu 25\%, Qu 25\%, Ga 20\% (mostly replaced by $\mathrm{Ch}$, with layers of quartz grains), sericite groundmass $25 \%$, Mag $5 \%$.

Sample used for determination of whole rock $\mathrm{Pb}$ isotopes.

S84-17: Siliceous carbonate gneiss with pseudomorphs after idocrase(?), west side of the north point, Spruce Island.
Mode: Ca 55\%, Bi 20\%, Idocrase (pseudomorphed to sericite) $15 \%$, Qu 7\%, Mag 3\%.

\section{Muscovite pegmatite}

S84-18: Muscovite pegmatite, intrudes marble, eastern part of north point on Spruce Island.

Mode: Or 35\%, Ab 25\%, Qu 23\%, Mu 7\%.

Zircon from this sample was used for $\mathrm{U}-\mathrm{Pb}$ age dating. 